\title{
Detection and diagnosis of large airway collapse: a systematic review
}

\author{
Alexandros Mitropoulos ${ }^{1}$, Woo-Jung Song ${ }^{2}$, Fatma Almaghlouth ${ }^{3}$, Samuel Kemp $\mathbb{C}^{1,3}$, Michael Polkey ${ }^{1,3}$ and \\ James H. Hull $\mathbb{D}^{1,3}$
}

${ }^{1}$ Dept of Respiratory Medicine, Royal Brompton Hospital, London, UK. ${ }^{2}$ Dept of Allergy and Clinical Immunology, Asan Medical Centre, University of Ulsan College of Medicine, Seoul, Korea. ${ }^{3}$ National Heart and Lung Institute, Imperial College, London, UK.

Corresponding author: James H. Hull (j.hull@rbht.nhs.uk)

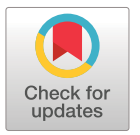

Copyright (C)The authors 2021

This version is distributed under the terms of the Creative Commons Attribution NonCommercial Licence 4.0. For commercial reproduction rights and permissions contact permissions@ersnet.org

This article has supplementary material available from openres.ersjournals.com.

Received: 1 Feb 2021 Accepted: 3 June 2021

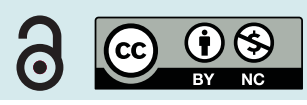

Shareable abstract (@ERSpublications)

CT is mostly used to diagnose LAC, and at a threshold used by most clinicians (i.e. $\geqslant 50 \%$ ) that would classify a large proportion of healthy individuals as being abnormal and LAC in a quarter of patients with chronic airway diseases https://bit.ly/3izAuSk

Cite this article as: Mitropoulos A, Song W-J, Almaghlouth F, et al. Detection and diagnosis of large airway collapse: a systematic review. ERJ Open Res 2021; 7: 00055-2021 [DOI: 10.1183/23120541.00055-2021].

\section{Abstract}

Large airway collapse (LAC) is a frequently encountered clinical problem, caused by tracheobronchomalacia +/- excessive dynamic airway collapse, yet there are currently no universally accepted diagnostic criteria. We systematically reviewed studies reporting a diagnostic approach to LAC in healthy adults and patients, to compare diagnostic modalities and criteria used. Electronic databases were searched for relevant studies between 1989 and 2019. Studies that reported a diagnostic approach using computed tomography (CT), magnetic resonance imaging or flexible fibreoptic bronchoscopy were included. Random effects meta-analyses were performed to estimate the prevalence of LAC in healthy subjects and in patients with chronic obstructive airway diseases. We included 41 studies, describing 10071 subjects ( $47 \%$ female) with a mean \pm SD age of $59 \pm 9$ years. Most studies $(n=35)$ reported CT findings, and only three studies reported bronchoscopic findings. The most reported diagnostic criterion was $\mathrm{a} \geqslant 50 \%$ reduction in tracheal or main bronchi calibre at end-expiration on dynamic expiratory CT. Meta-analyses of relevant studies found that 17\% (95\% CI: 0-61\%) of healthy subjects and 27\% (95\% CI: $11-46 \%)$ of patients with chronic airways disease were classified as having LAC, using this threshold. The most reported approach to diagnose LAC utilises CT diagnostics, and at a threshold used by most clinicians (i.e., $\geqslant 50 \%$ ) may classify a considerable proportion of healthy individuals as being abnormal and having LAC in a quarter of patients with chronic airways disease. Future work should focus on establishing more precise diagnostic criteria for LAC, relating this to relevant physiological and disease sequelae.

\section{Introduction}

The term large airway collapse (LAC) is used to describe a phenomenon in which the trachea and/or main bronchi demonstrate excessive inward movement during the expiratory phase of the respiratory cycle. This finding can be associated with troublesome and pervasive clinical features such as a barking cough, exertional dyspnoea and frequent respiratory tract infection [1].

Historically, several terms have been used to describe the entities causing LAC. Most often, the term tracheobronchomalacia (TBM) is used, but is strictly defined as a pathological weakness of the cartilaginous airway wall [2]. The term excessive dynamic airway collapse (EDAC) is used to describe exaggerated invagination of the posterior muscular tracheal membrane during expiration $[3,4]$.

It is estimated that some form of LAC may be present in approximately one in ten patients undergoing bronchoscopic examination for respiratory symptoms [5] and as many as a third of patients with COPD [6] or severe asthma [7]. In chronic airways disease, loss of elastic recoil combined with positive pleural pressures, especially during exercise or vigorous expiratory manoeuvres, can increase propensity to airway 
collapse [8]. The appearance of LAC may thus arise as a comorbid entity, in the presence of underlying airway disease, rather than representing a primary pathological problem or disease state per se. Regardless, the detection and characterisation of LAC is important, given several studies have now highlighted clinically meaningful improvements in exercise tolerance and quality of life (QoL) with targeted intervention, e.g. with the application of continuous positive airway pressure [9] and tracheobronchoplasty [10].

There is currently a lack of consensus regarding the criteria that should be used to diagnose LAC. Accordingly, whilst bronchoscopic or imaging techniques are often employed interchangeably to assess LAC, there is no agreement as to what constitutes an abnormal or "excessive" degree of collapse or how this differs between investigation modalities. The first description of diagnostic criteria for LAC are attributed to RAYL and colleagues [11], now over 50 years ago, reporting that airway collapse was abnormal if the airway lumen was reduced to one half or less during coughing. This magnitude of collapse became increasingly cited as being “diagnostic" of LAC [12, 13] and generally remains the most commonly applied criteria by pulmonologists currently. This degree or severity of collapse has, however, been found in a large proportion of entirely healthy, asymptomatic individuals [14]. Moreover, the diagnostic criteria used for LAC are potentially confounded by variation in the protocols employed to visualise and evaluate airway movement [1]. Thus overall, there is a risk of both potential over- and under-diagnosis, with associated implications for patient management.

The aim of this review was to systematically assess the published literature in this area and report differences in the criteria used in the diagnosis of LAC. A secondary aim was to undertake a synthesis of the literature assessing the prevalence of LAC in healthy individuals and in those with a clinical diagnosis of chronic airways disease. The various cut-off values and diagnostic modalities are critically appraised with the overall aim of helping to inform clinicians and researchers, evaluating this clinical entity and help direct development of future classification systems.

Methods

Protocol and registration

A systematic review of the available literature was performed using two electronic databases (PubMed and Embase). The search criteria employed included all eligible studies between January 1989 and October 2019 using the following keywords (airway collapse OR airway collapsibility OR bronchial collapse OR bronchial collapsibility OR tracheal collapse OR tracheal collapsibility OR expiratory collapse OR expiratory tracheal narrowing OR tracheomalacia OR tracheobronchomalacia OR bronchomalacia). Further detail on the search strategy is summarised in the online supplementary e-table 1 . The timeframe for included publications (i.e. only studies within the last 30 years) was selected to ensure relatively modern bronchoscopic, imaging equipment and techniques were employed and thus findings were applicable and relevant to current practice. The study was registered with PROPSPERO (CRD42019149347).

\section{Selection criteria}

Studies conducted in human subjects and published in English were considered for inclusion, providing they fulfilled the following criteria: 1) LAC had to be evaluated using either CT, magnetic resonance imaging (MRI) or flexible fibreoptic bronchoscopy; 2) the anatomic airway sites for evaluation of LAC had to be the trachea, main bronchi or both; 3) the cut-off values or the magnitude of LAC (TBM or EDAC) or the diagnostic approach had to be clearly reported in the study methodology and/or results section; 4) studies describing findings in children only were excluded; and 5) included case studies/series had to include at least three cases and thus single or double case report studies were excluded.

\section{Data extraction}

We extracted the following information: study aim (e.g. diagnosis of LAC), study design (e.g. prospective or retrospective), population characteristics (e.g. healthy adults or patients), diagnostic modality (e.g. CT, MRI or bronchoscopy), diagnostic criteria of LAC (e.g. $>50 \%$ collapse in the airway's cross-sectional area; CSA), main findings with prevalence of LAC and conclusions. This information was extracted from the original articles into an Excel spreadsheet (separated into columns such as study aim, study design, etc.), which was subsequently used as the data collection form.

\section{Quality assessment}

Study quality was assessed for those included in the meta-analysis sections addressing the prevalence of LAC in healthy subjects and patients with chronic airways disease (supplementary e-table 2). As there is no standard tool for assessing the quality of patient-based prevalence studies, we selected and modified items regarding external and internal validity from the assessment tools for population-based prevalence studies [15] and diagnostic studies [16], which included recruitment method, sample size justification, 
sample representativeness, risk of selection bias, appropriate exclusion criteria and outcome definition. Discrepancies in quality assessment were resolved by discussion between the lead authors.

\section{Statistical analysis and synthesis of results}

Estimation of the pooled prevalence of LAC was planned for certain populations (either in healthy controls or chronic airway diseases, where possible), using random effects meta-analyses to account for potential clinical and methodological heterogeneities in observational studies. Subgroup analysis was considered according to different threshold in the diagnostic criteria and modality for LAC. Heterogeneity was first assessed using a visual forest plot inspection and $I^{2}$ statistics. We considered funnel plot asymmetry and Egger's tests to assess publication bias if appropriate [17]. All statistical tests were two-tailed, and a p-value $<0.05$ was considered statistically significant. All meta-analyses were conducted using software MetaXL 5.3 (EpiGear International Pty Ltd, Brisbane, Australia).

Results

\section{Study selection}

The initial search strategy revealed 6446 articles. Following application of the PRISMA criteria, 41 papers satisfied the full selection criteria and were included in subsequent analysis (figure 1). The total sample size from these papers was 10071 subjects ( $\mathrm{n}=193$ healthy), of which 38 studies provided full subject demographic details describing a population with mean age of $59 \pm 9$ years, $47 \%$ of whom were female.

\section{Studies reporting bronchoscopic assessment}

\section{Subject characteristics}

Three studies describe the use of flexible bronchoscopy to assess LAC (table 1). These studies included 230 patients (age: $56.3 \pm 8.8$ years; $53 \%$ female) with a variety of clinical disease states including COPD, asthma, relapsing polychondritis and sarcoidosis [7, 18, 19]. However, over two-thirds of those identified (88\%) were patients with asthma, enrolled into a single trial [7]; with an asthmatic cohort $(\mathrm{n}=202)$ and a "control" cohort of subjects undergoing bronchoscopy as a reference group $(n=62$; age: $38.9 \pm 10.4 ; 38.7 \%$ female). The other two studies enrolled small numbers of patients ( $n=10$ and $n=18$, respectively) [18, 19], and we were unable to find any bronchoscopic studies evaluating LAC in entirely healthy, asymptomatic subjects.

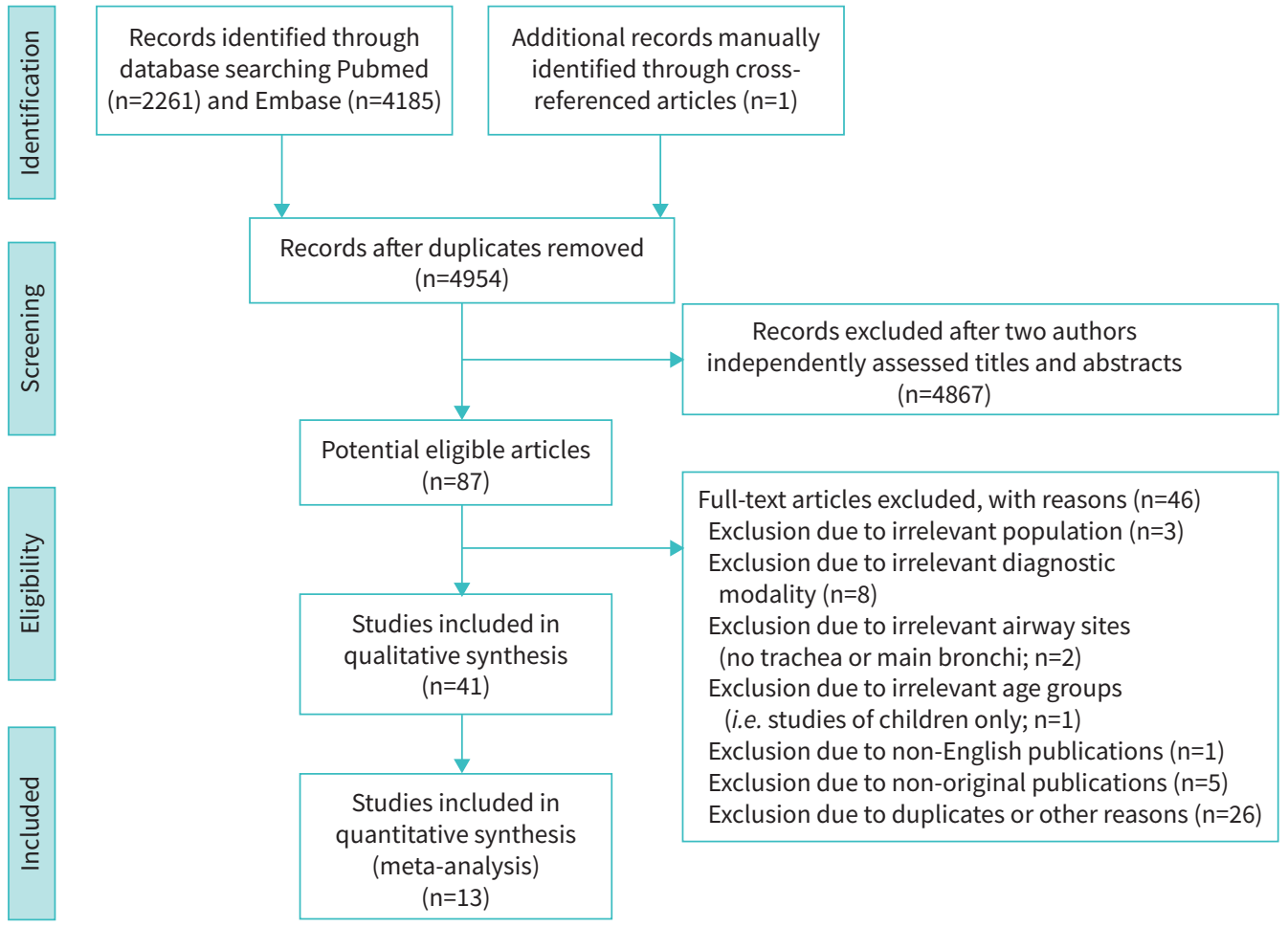

FIGURE 1 PRISMA flow chart for study selection. 


\begin{tabular}{|c|c|c|c|c|c|c|}
\hline $\begin{array}{l}\text { First author/ } \\
\text { year }\end{array}$ & Study purpose and design & Population & Diagnostic modality & Diagnostic criteria & Findings & Discussion \\
\hline $\begin{array}{l}\text { MAJID et al. } \\
2014 \text { [19] }\end{array}$ & $\begin{array}{l}\text { Prospective single-centre } \\
\text { study } \\
\text { Assessing inter- and } \\
\text { intra-observer } \\
\text { agreement in LAC }\end{array}$ & $\begin{array}{l}10 \text { patients (males }(n=4), \\
\text { females ( } n=6) \text {; mean age: } \\
65 \text { years, age range: } 43- \\
74 \text { years) with various } \\
\text { conditions }\end{array}$ & $\begin{array}{r}\text { Dynamic flexible } \\
\text { bronchoscopy }\end{array}$ & $\begin{array}{l}\text { TBM or EDAC } \geqslant 50 \% \\
\text { reduction in the } \\
\text { anteroposterior } \\
\text { diameter }\end{array}$ & $\begin{array}{l}\text { TBM was found in } 70 \% \\
\text { of patients }\end{array}$ & $\begin{array}{l}\text { There is intra- and interobserver } \\
\text { agreement among } \\
\text { pulmonologists and trainees } \\
\text { with various levels of } \\
\text { experience in the evaluation of } \\
\text { LAC }\end{array}$ \\
\hline $\begin{array}{l}\text { DaL Negro et al. } \\
2013 \text { [7] }\end{array}$ & $\begin{array}{l}\text { Prospective single-centre } \\
\text { study } \\
\text { Assessing the prevalence } \\
\text { of both TBM and EDAC }\end{array}$ & $\begin{array}{l}202 \text { asthmatics (males } \\
\text { ( } n=91), \text { females }(n=111) ; \\
\text { age: } 47.5 \pm 13.3 \text { years), and } \\
62 \text { subjects without any } \\
\text { obstructive disease } \\
\text { (males ( } n=38), \text { females } \\
\text { ( } n=24) ; \text { age: } 38.9 \\
\pm 10.4 \text { years) }\end{array}$ & $\begin{array}{r}\text { Dynamic flexible } \\
\text { bronchoscopy }\end{array}$ & $\begin{array}{l}\text { TBM or EDAC }>50 \% \text { of } \\
\text { airway collapse }\end{array}$ & $\begin{array}{l}\text { TBM and particularly } \\
\text { EDAC prevalence are } \\
\text { related to asthma } \\
\text { severity }\end{array}$ & $\begin{array}{l}\text { The presence of TBM or EDAC } \\
\text { should be considered when } \\
\text { bronchial asthma persists } \\
\text { despite appropriate } \\
\text { pharmacological treatment }\end{array}$ \\
\hline $\begin{array}{l}\text { MuRgu \& Colt, } \\
2007[18]\end{array}$ & $\begin{array}{l}\text { Retrospective } \\
\text { single-centre study } \\
\text { Assessing a } \\
\text { multidimensional } \\
\text { classification system } \\
\text { (FEMOS) for evaluating } \\
\text { patients with expiratory } \\
\text { LAC }\end{array}$ & $\begin{array}{l}18 \text { patients (males ( } n=13) \text {, } \\
\text { females }(n=5) ; 4 \text { with } \\
\text { EDAC and } 14 \text { with TBM) }\end{array}$ & Rigid bronchoscopy & $\begin{array}{l}\text { LAC, normal }<50 \% \text {, mild, } \\
\text { 50-75\%; moderate, } \\
75-100 \% \text {; and severe, } \\
100 \% \text { and the airway } \\
\text { walls make contact }\end{array}$ & $\begin{array}{l}\text { EDAC and TBM were } \\
\text { found in } 22.2 \% \text { and } \\
77.8 \% \text {, respectively }\end{array}$ & $\begin{array}{l}\text { Using FEMOS, the morphologies } \\
\text { and aetiologies of LAC can be } \\
\text { identified and stratified } \\
\text { objectively based on the } \\
\text { degree of functional } \\
\text { impairment, extent of disease } \\
\text { and severity of airway collapse }\end{array}$ \\
\hline
\end{tabular}


Protocols employed

Two studies employed flexible bronchoscopy [7, 19], with the patient in a supine position; and one study utilised both flexible and rigid approach [18]. Scope placement was varied across the studies with evaluation performed at the level of the trachea, carina and main bronchi and under conscious sedation, in the flexible studies [7, 18, 19]. The breathing manoeuvres undertaken during bronchoscopy are described as dynamic or forced inspiration and expiration manoeuvres with luminal dimensions measured at the end of both forced inhalation and exhalation were performed at five sites, namely, proximal, mid- and distal trachea, and at right and left main-stem bronchus [7, 19]. In the study by MAJID et al. [19], the expiratory phase collapse patients were evaluated by instructing subjects to take a deep breath, hold it and blow it out. In the study by DaL Negro et al. [7], collapse was assessed spontaneously and following a physician's instruction to perform deep breathing, forced exhalation and coughing. One study did not report the specific breathing instructions [18], and there were no details providing compliance or non-cooperation during these breathing procedures.

All studies $(n=3)$ defined LAC as a $>50 \%$ airway collapse and provided a semi-quantitative description of LAC, using pre-defined cut-off thresholds (i.e., normal $<50 \%$, mild 50-75\%, moderate $75-100 \%$ and severe 100\%) (figure 2). Murgu and Colt [18] also report a novel scoring system, by combining bronchoscopic findings with a multidimensional classification system (termed the FEMOS classification). In the FEMOS classification, the extent (from normal to diffuse), morphology (TBM type or not) and severity (normal $<50 \%$, mild $50-75 \%$, moderate $75-100 \%$ and severe $100 \%$ ) of airway collapse is combined with the functional status of the subject as classified by level of dyspnoea to provide an overall classification score. This classification system was also employed to describe LAC in the 264 subjects in the series of Dal Negro and colleagues [7]. Masid et al. [19] utilised pre-defined cut-off thresholds (as described above) to assess the degree of LAC and showed an interobserver and intra-observer interclass correlation coefficient of 0.81 and 0.89 , respectively.

\section{Studies reporting imaging-based assessment \\ Computed tomography \\ Subject characteristics}

The studies ( $\mathrm{n}=35$ ) using CT to assess LAC are presented in table 2. These studies included a total of 10 402 participants of which 10244 were patients (age: 58.4 \pm 9.3 years; $47 \%$ female) with conditions such as COPD, asthma, relapsing polychondritis and sarcoidosis. There were also data available in 158 healthy subjects (age: $50.9 \pm 4.1$ years; $42 \%$ female).

\section{Protocols employed}

The majority of the protocols describe utilising a helical or spiral CT (27 out of 35 studies) technique, whilst the remaining studies use cine-acquisition. The most commonly utilised breathing manoeuvre described during CT scanning was paired end-inspiratory-dynamic expiratory (used in 33 out of 35 studies). Two studies instructed the patients to cough [20] and to hold their breath [21] during scanning.

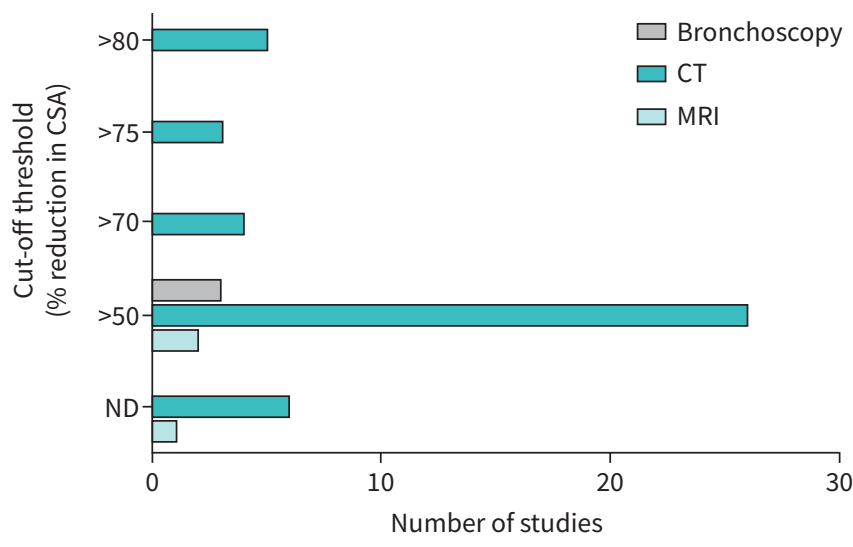

FIGURE 2 Study cut-off thresholds reported for the diagnosis of large airway collapse, based on diagnostic modality. CSA: cross-sectional area; CT: computed tomography; MRI: magnetic resonance imaging. 
TABLE 2 Computed tomographic and magnetic resonance imaging studies

\begin{tabular}{|c|c|c|c|c|c|c|}
\hline First author/year & Study purpose and design & Population & Diagnostic modality & Diagnostic criteria & Findings & Discussion \\
\hline $\begin{array}{l}\text { BEZUIDENHOUT et al. } \\
2019 \text { [51] }\end{array}$ & $\begin{array}{l}\text { Retrospective single-centre } \\
\text { study } \\
\text { To evaluate patients with } \\
\text { TBM after undergoing } \\
\text { tracheobronchoplasty }\end{array}$ & $\begin{array}{l}18 \text { patients (males }(n=5) \\
\text { females ( } n=13) ; \text { mean age: } \\
65 \pm 12 \text { years) with COPD } \\
(n=7), \text { GERD }(n=14), \text { OSA } \\
(n=8), \text { cardiac disease }(n=4)\end{array}$ & $\begin{array}{l}\text { 8-, 16- and 64-MDCT } \\
\text { scan }\end{array}$ & $\begin{array}{l}\mathrm{LAC} \geqslant 70 \% \text { reduction } \\
\text { in the CSA }\end{array}$ & $\begin{array}{l}\text { Mean tracheal } \\
\text { collapsibility improved } \\
\text { by } 34 \% \text { in } \\
\text { post-operative CT }\end{array}$ & $\begin{array}{l}\text { Dynamic CT could play an } \\
\text { important role in assessing } \\
\text { response to } \\
\text { tracheobronchoplasty }\end{array}$ \\
\hline $\begin{array}{l}\text { NygaARD et al. } \\
2019[29]\end{array}$ & $\begin{array}{l}\text { Retrospective/prospective } \\
\text { single-centre study } \\
\text { To assess TM over time (2 } \\
\text { CT scans) in patients with } \\
\text { excessive tracheal } \\
\text { collapse }\end{array}$ & $\begin{array}{l}20 \text { patients with respiratory } \\
\text { diseases (males }(n=6) \\
\text { females }(n=14) ; \text { mean age: } \\
68 \text { years) }\end{array}$ & $\begin{array}{l}\text { high-resolution } \\
\text { MDCT scan }\end{array}$ & $\begin{array}{l}\mathrm{TM} \geqslant 50 \% \text { reduction } \\
\text { in the } \mathrm{CSA}\end{array}$ & $\begin{array}{l}\text { Seven patients showed a } \\
\text { tracheal collapse } \\
\text { progression ( }>10 \% \\
\text { difference) between } \\
\text { the scans }\end{array}$ & $\begin{array}{l}\text { Tracheal collapse regressed in } \\
\text { half of the patients over a } \\
\text { time period of } 2 \text { years }\end{array}$ \\
\hline $\begin{array}{l}\text { CIET et al. } 2017 \\
\text { [31] }\end{array}$ & $\begin{array}{l}\text { Prospective single-centre } \\
\text { study } \\
\text { Comparison of MRI to } \\
\text { MDCT in assessing TBM }\end{array}$ & $\begin{array}{l}12 \text { participants (males }(n=5) \\
\text { females }(n=7) ; 9 \text { healthy } \\
\text { adults and } 3 \text { patients with } \\
\text { COPD; mean age: } 64.5 \text { years, } \\
\text { age range: } 45-77 \text { years) }\end{array}$ & $\begin{array}{l}\text { 1.5-T Signa MRI } \\
\text { 64-MDCT scan }\end{array}$ & $\begin{array}{l}\text { Criterion was not } \\
\text { defined }\end{array}$ & $\begin{array}{l}\text { TM was } 52 \% \text { and } 77 \% \\
\text { and } \mathrm{BM} \text { was } 55 \% \text { and } \\
63 \% \text { during FVC for } \\
\text { healthy and COPD } \\
\text { patients, respectively }\end{array}$ & $\begin{array}{l}\text { MRI was found to be a } \\
\text { technically feasible } \\
\text { alternative to MDCT for } \\
\text { assessing TBM }\end{array}$ \\
\hline $\begin{array}{l}\text { NygaARD et al. } \\
2017 \text { [30] }\end{array}$ & $\begin{array}{l}\text { Retrospective single-centre } \\
\text { study } \\
\text { To compare four different } \\
\text { image analysis methods } \\
\text { for the diagnosis of } \\
\text { tracheal collapse using } \\
\text { MDCT }\end{array}$ & $\begin{array}{l}353 \text { patients (males ( } n=150 \text { ), } \\
\text { females ( } n=191), \text { mean age: } \\
60 \text { years, age range: } 18- \\
88 \text { years) with respiratory } \\
\text { diseases (e.g. COPD, ILD, } \\
\text { bronchiectasis) }\end{array}$ & 64-MDCT scan & $\begin{array}{l}\mathrm{LAC}>50 \% \text { and }>80 \% \\
\text { reduction in the } \\
\text { CSA }\end{array}$ & $\begin{array}{l}\text { LAC prevalence was } \\
\quad 15.1 \% \text { when using } \\
>50 \% \text { as a threshold }\end{array}$ & $\begin{array}{l}\text { The different image analysis } \\
\text { methods identified LAC in } \\
\text { different patients. Thus, the } \\
\text { diagnosis of LAC should not } \\
\text { solely rely on MDCT images }\end{array}$ \\
\hline $\begin{array}{l}\text { LeONG et al. } 2017 \\
\text { [6] }\end{array}$ & $\begin{array}{l}\text { Prospective single-centre } \\
\text { study } \\
\text { To explore the prevalence } \\
\text { of ECAC in stable and } \\
\text { acute exacerbations } \\
\text { COPD (AECOPD) patients }\end{array}$ & $\begin{array}{l}40 \text { COPD patients (males } \\
\text { ( } \mathrm{n}=19) \text {, females ( } \mathrm{n}=21) ; \text { age: } \\
70.1 \pm 8.2 \text { years); } 64 \text { AECOPD } \\
\text { (males ( } \mathrm{n}=40) \text {, females } \\
(\mathrm{n}=24) ; \text { age: } 70.2 \pm 11.6 \text { years); } \\
53 \text { healthy volunteers (males } \\
(\mathrm{n}=35) \text {, females ( } \mathrm{n}=18) ; \text { age: } \\
56.6 \pm 16.9 \text { years) }\end{array}$ & $\begin{array}{l}\text { 320-slice dynamic } \\
\text { MDCT }\end{array}$ & $\begin{array}{l}\text { LAC }>50 \%,>75 \% \text { and } \\
>80 \% \text { reduction in } \\
\text { the CSA were } \\
\text { compared }\end{array}$ & $\begin{array}{l}\text { ECAC was observed in } \\
35 \% \text { of COPD, } 39 \% \text { of } \\
\text { AECOPD and no } \\
\text { healthy individuals } \\
\text { when a }>50 \% \text { was used } \\
\text { as a criterion }\end{array}$ & $\begin{array}{l}\text { ECAC can be present in up to } \\
\text { one third of patients with } \\
\text { stable COPD, and the } \\
\text { abnormality does not seem } \\
\text { to be worsened during } \\
\text { AECOPD }\end{array}$ \\
\hline $\begin{array}{l}\text { BHATT et al. } 2016 \\
\text { [44] }\end{array}$ & $\begin{array}{l}\text { Retrospective multicentre } \\
\text { study } \\
\text { Assessing the association } \\
\text { of ECAC to lung disease } \\
\text { in smokers }\end{array}$ & $\begin{array}{l}8820 \text { ex- or active smokers } \\
(43.7 \% \text { had COPD and } 16.6 \% \\
\text { had asthma (males } \\
(n=4667), \text { females ( } n=4153) ; \\
\text { mean age: } 59.7 \pm 6.9 \text { years)) }\end{array}$ & CT scan & $\begin{array}{l}\mathrm{ECAC} \geqslant 50 \% \\
\quad \text { reduction in CSA }\end{array}$ & $\begin{array}{l}\text { ECAC prevalence was } 5 \% \\
\text { in ex- or active } \\
\text { smokers and } 5.9 \% \text { in } \\
\text { participants with COPD } \\
(n=229 / 3856)\end{array}$ & $\begin{array}{l}\text { The presence of ECAC was } \\
\text { associated with worse } \\
\text { respiratory quality of life in } \\
\text { current or former smokers }\end{array}$ \\
\hline $\begin{array}{l}\text { SindHWANI et al. } \\
2016 \text { [34] }\end{array}$ & $\begin{array}{l}\text { Prospective single-centre } \\
\text { study } \\
\text { To assess expiratory } \\
\text { wheeze in patients with } \\
\text { obstructive airway } \\
\text { disorders }\end{array}$ & $\begin{array}{l}25 \text { patients (males ( } n=14 \text { ), } \\
\text { females ( } n=11), \text { mean age: } \\
62.7 \pm 7.81 \text { years) with COPD }\end{array}$ & CT scan & $\begin{array}{l}\text { TBM/EDAC } \geqslant 50 \% \\
\text { reduction of the } \\
\text { airway lumen }\end{array}$ & $\begin{array}{l}\text { TBM/EDAC was found in } \\
40 \% \text { of COPD patients }\end{array}$ & $\begin{array}{l}\text { Findings indicate value of } \\
\text { screening patients with } \\
\text { obstructive airway disease } \\
\text { for TBM/EDAC }\end{array}$ \\
\hline
\end{tabular}




\begin{tabular}{|c|c|c|c|c|c|c|}
\hline First author/year & Study purpose and design & Population & Diagnostic modality & Diagnostic criteria & Findings & Discussion \\
\hline $\begin{array}{l}\text { EL SoRougl et al. } \\
2016 \text { [33] }\end{array}$ & $\begin{array}{l}\text { Prospective single-centre } \\
\text { study } \\
\text { To determine the } \\
\text { prevalence of TM in } \\
\text { COPD patients }\end{array}$ & $\begin{array}{l}30 \text { patients with COPD } \\
\text { (demographics were not } \\
\text { reported) }\end{array}$ & 64-MDCT scan & $\begin{array}{l}\mathrm{TM} \geqslant 50 \% \text { in the } \\
\text { tracheal lumen } \\
\mathrm{CSA}\end{array}$ & $\begin{array}{l}20 \% \text { of COPD patients } \\
\text { showed evidence of TM }\end{array}$ & $\begin{array}{l}\text { A significant proportion of } \\
\text { patients with COPD had } \\
\text { features consistent with TM } \\
\text { on dynamic CT scanning }\end{array}$ \\
\hline $\begin{array}{l}\text { WEINSTEIN et al. } \\
2016 \text { [52] }\end{array}$ & $\begin{array}{l}\text { Prospective single-centre } \\
\text { study } \\
\text { To describe the imaging } \\
\text { characteristics of people } \\
\text { presenting exertional } \\
\text { dyspnoea }\end{array}$ & $\begin{array}{l}6 \text { military personnel (males } \\
(n=5), \text { females }(n=1) \text {, mean } \\
\text { age: } 39.5 \text { years, age range: } \\
24 \text { to } 53 \text { years) with no } \\
\text { underlying lung disease }\end{array}$ & $\begin{array}{l}\text { CT scan } \\
\text { Bronchoscopy at rest } \\
\text { and during exercise } \\
\text { (cycling; } n=2 \text { ). }\end{array}$ & $\begin{array}{l}E D A C \geqslant 75 \% \\
\text { reduction of the } \\
\text { airway lumen }\end{array}$ & $\begin{array}{l}\text { EDAC was detected on } \\
\text { expiratory images } \\
\text { during dynamic CT } \\
(n=2)\end{array}$ & $\begin{array}{l}\text { EDAC may explain } \\
\text { "unexplained” exertional } \\
\text { dyspnoea and wheeze in } \\
\text { military recruits }\end{array}$ \\
\hline $\begin{array}{l}\text { RepresAs-RepresAS } \\
\text { et al. } 2015 \text { [43] }\end{array}$ & $\begin{array}{l}\text { Prospective single-centre } \\
\text { study } \\
\text { To investigate the } \\
\text { prevalence of EDAC in } \\
\text { COPD }\end{array}$ & $\begin{array}{l}53 \text { patients (males ( } n=46), \\
\text { females ( } n=7) \text {, mean age: } 65 \\
\pm 9 \text { years) with COPD }\end{array}$ & Helicoidal MDCT & $\begin{array}{l}\mathrm{EDAC}>50 \% \text { reduction } \\
\text { in } \mathrm{CSA}\end{array}$ & $\begin{array}{l}\text { Prevalence of EDAC was } \\
9.4 \%\end{array}$ & $\begin{array}{l}\text { EDAC in COPD patients is } \\
\text { independent of disease } \\
\text { severity and may not relate } \\
\text { to symptoms }\end{array}$ \\
\hline $\begin{array}{l}\text { O'Donnell et al. } \\
2014[25]^{q}\end{array}$ & $\begin{array}{l}\text { Prospective single-centre } \\
\text { study } \\
\text { To determine the tracheal } \\
\text { collapse in COPD patients }\end{array}$ & $\begin{array}{l}67 \text { patients (males ( } n=38), \\
\text { females ( } n=29) ; \text { age: } 65.1 \\
\pm 6.5 \text { years) with COPD }\end{array}$ & $\begin{array}{l}\text { 64-detector row } \mathrm{CT} \\
\text { scan }\end{array}$ & $\begin{array}{l}\text { Tracheal collapse } \\
\geqslant 80 \% \text { reduction in } \\
\text { CSA }\end{array}$ & $\begin{array}{l}\text { Average forced expiratory } \\
\text { collapse }(62 \pm 16 \%) \text { was } \\
\text { greater to } \\
\text { end-expiratory collapse } \\
(17 \pm 18 \%)\end{array}$ & $\begin{array}{l}\text { COPD patients display a wide } \\
\text { range of tracheal collapse at } \\
\text { end-expiration }\end{array}$ \\
\hline $\begin{array}{c}\text { WieLPÜTz et al. } \\
2014 \text { [53] }\end{array}$ & $\begin{array}{l}\text { Prospective single-centre } \\
\text { study } \\
\text { To assess the feasibility of } \\
\text { low-dose MDCT }\end{array}$ & $\begin{array}{l}3 \text { patients ( } 3 \text { males; mean age: } \\
63.3 \text { years) with COPD }\end{array}$ & 4D MDCT scan & $\begin{array}{l}\text { TM criterion was not } \\
\text { reported }\end{array}$ & $\begin{array}{l}\text { EDAC }(n=1) \text {, sabre-sheath } \\
\text { trachea and TBM }(n=1), \\
\text { as well as tracheal } \\
\text { stenosis }(n=1) \text { were } \\
\text { demonstrated }\end{array}$ & $\begin{array}{l}\text { Low-dose MDCT may have } \\
\text { equal diagnostic impact as } \\
\text { bronchoscopy for tracheal } \\
\text { instability }\end{array}$ \\
\hline $\begin{array}{l}\text { BoIselLe et al. } \\
2013[54]\end{array}$ & $\begin{array}{l}\text { Prospective single-centre } \\
\text { study } \\
\text { To assess the tracheal } \\
\text { collapse in morbidly } \\
\text { obese, non-morbidly } \\
\text { obese and normal } \\
\text { weight COPD patients }\end{array}$ & $\begin{array}{l}100 \text { patients (males ( } n=52) \\
\text { females ( } n=48) \\
\text { mean age: } 65 \pm 7 \text { years) with } \\
\text { COPD }\end{array}$ & 64-detector CT scan & $\begin{array}{l}\text { LAC criterion was not } \\
\text { reported }\end{array}$ & $\begin{array}{l}\text { Expiratory collapse was } \\
\text { directly associated } \\
\text { with BMI }(p=0.002)\end{array}$ & $\begin{array}{l}\text { Obesity is positively correlated } \\
\text { with the degree of expiratory } \\
\text { tracheal collapse } \\
\text { among COPD patients }\end{array}$ \\
\hline $\begin{array}{l}\text { O'Donnell et al. } \\
2012[40]^{\#}\end{array}$ & $\begin{array}{l}\text { Prospective single-centre } \\
\text { study } \\
\text { To explore the association } \\
\text { between forced } \\
\text { expiratory tracheal } \\
\text { collapse and age or sex }\end{array}$ & $\begin{array}{l}81 \text { healthy volunteers (males } \\
(n=41) \text {, females }(n=40) \text {; age: } \\
47 \pm 17 \text { years) }\end{array}$ & $\begin{array}{l}\text { 64-detector-row CT } \\
\text { scan }\end{array}$ & $\begin{array}{l}\text { Tracheal } \\
\text { collapse } \geqslant 80 \% \\
\text { reduction in CSA }\end{array}$ & $\begin{array}{l}\text { The mean \% collapse was } \\
\text { similar for males ( } 55 \\
\pm 23 \% \text { ) and females ( } 52 \\
\pm 17 \%) \text {. The mean } \% \\
\text { collapse was correlated } \\
\text { to age }\left(r^{2}=0.40, p<\right. \\
0.001) \text { in males }\end{array}$ & $\begin{array}{l}\text { Age and sex should be } \\
\text { considered when assessing } \\
\text { forced expiratory airway } \\
\text { collapse for suspected TM }\end{array}$ \\
\hline $\begin{array}{l}\text { BoIselLe et al. } \\
2012[24]^{\oplus}\end{array}$ & $\begin{array}{l}\text { Prospective single-centre } \\
\text { study } \\
\text { To determine the } \\
\text { prevalence of tracheal } \\
\text { collapse in COPD patients }\end{array}$ & $\begin{array}{l}100 \text { patients (males ( } n=52) \\
\quad \text { females ( } n=48) ; \text { age: } 65 \\
\pm 7 \text { years) with COPD }\end{array}$ & $\begin{array}{l}\text { 64-detector-row CT } \\
\text { scan }\end{array}$ & $\begin{array}{l}\text { Tracheal collapse } \\
\geqslant 80 \% \text { reduction in } \\
\text { CSA }\end{array}$ & $\begin{array}{l}\text { Prevalence of TM was } \\
\text { found in } 20 \\
\text { participants }(20 \%)\end{array}$ & $\begin{array}{l}\text { TM is observed in a subset of } \\
\text { patients with COPD, but the } \\
\text { magnitude of collapse is } \\
\text { independent of disease } \\
\text { severity }\end{array}$ \\
\hline
\end{tabular}




\begin{tabular}{|c|c|c|c|c|c|c|}
\hline First author/year & Study purpose and design & Population & Diagnostic modality & Diagnostic criteria & Findings & Discussion \\
\hline $\begin{array}{l}\text { BoIselLe et al. } \\
2010[32]\end{array}$ & $\begin{array}{l}\text { Prospective single-centre } \\
\text { study } \\
\text { To assess the } \\
\text { reproducibility of MDCT } \\
\text { in measuring TM in } \\
\text { healthy volunteers over } \\
\text { time }\end{array}$ & $\begin{array}{l}14 \text { healthy volunteers (males } \\
(n=6) \text {, females }(n=8) \text {, mean } \\
\text { age: } 48.7 \pm 13.8 \text { years) }\end{array}$ & 64-MDCT scan & $\begin{array}{l}\text { TM criterion was not } \\
\text { reported }\end{array}$ & $\begin{array}{l}\text { 1st and } 2 n d \text { year } \\
\text { measures of tracheal } \\
\text { collapse were strongly } \\
\text { associated }\left(r^{2}=0.98,\right. \\
p<0.001)\end{array}$ & $\begin{array}{l}\text { MDCT measurements of forced } \\
\text { expiratory } \\
\text { tracheal collapse in healthy } \\
\text { volunteers is highly } \\
\text { reproducible } \\
\text { over time }\end{array}$ \\
\hline $\begin{array}{l}\text { Litmanovich et al. } \\
2010\left[^{26}\right]^{\#}\end{array}$ & $\begin{array}{l}\text { Prospective single-centre } \\
\text { study } \\
\text { To assess the forced } \\
\text { expiratory bronchial } \\
\text { collapsibility in healthy } \\
\text { volunteers }\end{array}$ & $\begin{array}{l}51 \text { healthy volunteers (males } \\
\quad(n=25) \text {, females }(n=26) \text {; age: } \\
50 \pm 15 \text { years) }\end{array}$ & $\begin{array}{l}\text { 64-detector row MDCT } \\
\text { scan }\end{array}$ & $\begin{array}{l}\text { Expiratory reduction } \\
\text { in CSA of }>50 \% \\
\text { and }>80 \% \text {, were } \\
\text { both used }\end{array}$ & $\begin{array}{l}73 \% \text { of participants met } \\
\text { the criterion }(>50 \%) \text { in } \\
\text { one or both bronchi }\end{array}$ & $\begin{array}{l}\text { The current data suggest the } \\
\text { need for more rigorous } \\
\text { criteria for the diagnosis of } \\
\text { BM }\end{array}$ \\
\hline $\begin{array}{l}\text { WAGNETZ et al. } \\
2010[28]\end{array}$ & $\begin{array}{l}\text { Prospective single-centre } \\
\text { study } \\
\text { To establish the use of a } \\
\text { novel MDCT for the } \\
\text { evaluation of TM }\end{array}$ & $\begin{array}{l}6 \text { patients (males ( } n=5) \text {, } \\
\text { females ( } n=1) \text {; mean age: } \\
53 \text { years, age range: } 37 \text { to } \\
70 \text { years) with suspected TM } \\
\text { (medical history was not } \\
\text { reported) }\end{array}$ & $\begin{array}{l}\text { 320-row MDCT scan } \\
\text { and fibreoptic } \\
\text { bronchoscopy }\end{array}$ & $\begin{array}{l}\mathrm{TM} / \mathrm{TBM} \geqslant 50 \% \\
\text { reduction in CSA }\end{array}$ & $\begin{array}{l}\text { All patients demonstrated } \\
\text { TM/TBM with varying } \\
\text { degrees of airway } \\
\text { collapse ( } 50 \% \text { to }>90 \% \\
\text { of the CSA) }\end{array}$ & $\begin{array}{l}\text { The 4D MDCT, isotropic, } \\
\text { isovolumetric and isophasic, } \\
\text { of the central airway is } \\
\text { promising for the diagnosis } \\
\text { of TM/TBM }\end{array}$ \\
\hline $\begin{array}{l}\text { BoIselLe et al. } \\
2009[14]^{\#}\end{array}$ & $\begin{array}{l}\text { Prospective single-centre } \\
\text { study } \\
\text { To assess the tracheal } \\
\text { collapsibility in healthy } \\
\text { volunteers }\end{array}$ & $\begin{array}{l}51 \text { healthy volunteers (males } \\
(n=25) \text {, females ( } n=26) \text {; age: } \\
50 \pm 15 \text { years) }\end{array}$ & $\begin{array}{l}\text { 64-detector row MDCT } \\
\text { scan }\end{array}$ & $\begin{array}{l}\text { Expiratory reduction } \\
\text { in CSA of }>50 \%\end{array}$ & $\begin{array}{l}78 \% \text { of healthy } \\
\text { volunteers exceeded } \\
\text { the current diagnostic } \\
\text { criterion for TM }\end{array}$ & $\begin{array}{l}\text { This study emphasises the } \\
\text { need for a more rigorous } \\
\text { diagnostic criterion to } \\
\text { prevent overdiagnosis of TM }\end{array}$ \\
\hline $\begin{array}{l}\text { McDermott et al. } \\
2009 \text { [39] }\end{array}$ & $\begin{array}{l}\text { Prospective single-centre } \\
\text { study } \\
\text { To determine the } \\
\text { prevalence and severity } \\
\text { of TM in adults with CF }\end{array}$ & $\begin{array}{l}40 \text { patients (males ( } n=22) \text {, } \\
\text { females ( } n=18) \text {; mean age: } \\
28 \pm 8 \text {, age range: } 18-54 \text { ) with } \\
\text { CF and } 10 \text { controls }\end{array}$ & $\begin{array}{l}\text { Dynamic cine MDCT } \\
\text { with } 64 \text {-detector } \\
\text { row }\end{array}$ & $\begin{array}{l}\mathrm{TM}>50 \% \text { or }>75 \% \\
\text { reduction in CSA } \\
\text { during cough }\end{array}$ & $\begin{array}{l}\text { TM was found in } 69 \% \text { of } \\
\text { patients with CF during } \\
\text { forced expiration and } \\
\text { in } 29 \% \text { during } \\
\text { coughing }\end{array}$ & $\begin{array}{l}\text { TM depicted at dynamic cine } \\
\text { MDCT is a highly prevalent } \\
\text { finding in patients with CF }\end{array}$ \\
\hline $\begin{array}{l}\text { InOUE et al. } 2009 \\
\text { [45] }\end{array}$ & $\begin{array}{l}\text { Retrospective single-centre } \\
\text { study } \\
\text { To evaluate the frequency } \\
\text { of TBM associated } \\
\text { with PE }\end{array}$ & $\begin{array}{l}56 \text { patients (males ( } n=55) \text {, } \\
\text { females ( } n=1) \text {; mean age: } \\
68.9 \text { years, age range: } 49- \\
87 \text { years) with PE }\end{array}$ & $\begin{array}{l}\text { MDCT scanner with } \\
\text { two-detector row }\end{array}$ & $\begin{array}{l}\text { TBM } \geqslant 50 \% \text { decrease } \\
\text { in CSA }\end{array}$ & $\begin{array}{l}\text { Four }(7.1 \%) \text { patients were } \\
\text { diagnosed as having } \\
\text { TM or BM }\end{array}$ & $\begin{array}{l}\text { TBM might be under- } \\
\text { diagnosed in some patients } \\
\text { with PE when using the } \\
\text { standard criterion (e.g. } \\
\geqslant 50 \%)\end{array}$ \\
\hline $\begin{array}{l}\text { Ochs et al. } 2009 \\
{[46]}\end{array}$ & $\begin{array}{l}\text { Retrospective multicentre } \\
\text { study } \\
\text { To investigate the } \\
\text { prevalence of TM in an } \\
\text { emphysema cohort }\end{array}$ & $\begin{array}{l}431 \text { patients (males ( } n=267, \\
\text { mean age: } 64 \text { years, range: } \\
41 \text { to } 76 \text { ), females ( } n=164, \\
\text { mean age: } 62 \text { years, range: } \\
41 \text { to } 76) \text { ) }\end{array}$ & CT scan & $\begin{array}{l}\mathrm{LAC} \geqslant 50 \%, \text { and }>70 \% \\
\text { in the } \mathrm{CSA}\end{array}$ & $\begin{array}{l}\text { Prevalence of TM was } \\
\text { found in } 13.4 \% \\
\text { participants based on } \\
\geqslant 50 \% \text { criterion }\end{array}$ & $\begin{array}{l}\text { A large degree of tracheal } \\
\text { collapse can be found at } \\
\text { end-expiration in patients } \\
\text { with emphysema }\end{array}$ \\
\hline $\begin{array}{l}\text { FerRetti et al. } \\
2008 \text { [27] }\end{array}$ & $\begin{array}{l}\text { Prospective single-centre } \\
\text { study } \\
\text { To compare dynamic and } \\
\text { end-expiratory imaging to } \\
\text { assess LAC in patients } \\
\text { with suspected TBM }\end{array}$ & $\begin{array}{l}70 \text { patients (males ( } n=43 \text { ), } \\
\text { females ( } n=27) \text {; mean age: } \\
57 \text { years, age range: } 12- \\
79 \text { years) with respiratory } \\
\text { conditions (e.g. COPD) }\end{array}$ & $\begin{array}{l}\text { 16-detector row } \\
\text { helical CT scan }\end{array}$ & TBM was not defined & $\begin{array}{l}\text { TBM was not found at } \\
\text { the end of expiration, } \\
\text { but its prevalence was } \\
13 \% \text { during dynamic } \\
\text { expiration }\end{array}$ & $\begin{array}{l}\text { Dynamic expiratory CT } \\
\text { demonstrates a greater } \\
\text { degree of LAC than the } \\
\text { end-expiratory acquisition in } \\
\text { patients with suspected TBM }\end{array}$ \\
\hline
\end{tabular}




\begin{tabular}{|c|c|c|c|c|c|c|}
\hline First author/year & Study purpose and design & Population & Diagnostic modality & Diagnostic criteria & Findings & Discussion \\
\hline $\begin{array}{l}\text { LeE et al. } 2007 \\
\quad[50]\end{array}$ & $\begin{array}{l}\text { Retrospective single-centre } \\
\text { study } \\
\text { To compare the dynamic } \\
\text { expiratory CT against } \\
\text { bronchoscopy for } \\
\text { detecting airway malacia }\end{array}$ & $\begin{array}{l}29 \text { patients (males ( } n=12 \text { ), } \\
\text { females ( } n=17), \text { mean age: } \\
60 \text { years, age range: } 36 \text { to } \\
79 \text { years) with COPD and } \\
\text { relapsing polychondritis }\end{array}$ & MDCT helical scan & $\begin{array}{l}\mathrm{LAC}>50 \% \text { reduction } \\
\text { in CSA }\end{array}$ & $\begin{array}{l}\text { CT findings were } \\
\text { concordant with } \\
\text { bronchoscopy in } 97 \% \\
\text { of patients }\end{array}$ & $\begin{array}{l}\mathrm{CT} \text { is a highly sensitive method } \\
\text { for detecting airway malacia } \\
\text { and could serve as an } \\
\text { effective, noninvasive test for } \\
\text { diagnosing LAC }\end{array}$ \\
\hline $\begin{array}{l}\text { BoIsELLE et al. } \\
2006[20]\end{array}$ & $\begin{array}{l}\text { Prospective single-centre } \\
\text { study } \\
\text { To describe } \\
\text { the technical aspects of } \\
\text { using 64-MDCT during } \\
\text { coughing }\end{array}$ & $\begin{array}{l}17 \text { patients (males }(n=6) \text {, } \\
\text { females ( } n=11) \text {, age range: } \\
62.4 \text { years) with suspected } \\
\text { TM }\end{array}$ & 64-MDCT scan & $\begin{array}{l}\mathrm{TM}>50 \% \text { reduction } \\
\text { in CSA during } \\
\text { coughing }\end{array}$ & $\begin{array}{l}\text { 64-MDCT during a } \\
\text { coughing protocol was } \\
\text { technically successful } \\
\text { in } 94 \% \text { of patients }\end{array}$ & $\begin{array}{l}\text { 64-MDCT is technically feasible } \\
\text { and has the potential to } \\
\text { make significant } \\
\text { contributions to the } \\
\text { noninvasive diagnosis of TM }\end{array}$ \\
\hline $\begin{array}{l}\text { LeE et al. } 2006 \\
\text { [55] }\end{array}$ & $\begin{array}{l}\text { Retrospective single-centre } \\
\text { study } \\
\text { To assess the prevalence } \\
\text { of expiratory CT } \\
\text { abnormalities, including } \\
\text { malacia }\end{array}$ & $\begin{array}{l}18 \text { patients (males ( } n=3 \text { ), } \\
\text { females ( } n=15) \text {, mean age: } \\
47 \text { years; age range: } 20- \\
71 \text { years) with relapsing } \\
\text { polychondritis }\end{array}$ & Helical MDCT & $\begin{array}{l}\mathrm{LAC}>50 \% \text { reduction } \\
\text { in } \mathrm{CSA}\end{array}$ & $\begin{array}{l}\text { CT abnormalities were } \\
\text { present in } 94 \% \text { and } \\
\text { airway malacia in } 72 \% \\
\text { of patients }\end{array}$ & $\begin{array}{l}\text { Dynamic expiratory CT should } \\
\text { be considered a standard } \\
\text { component of airway } \\
\text { evaluation in patients with } \\
\text { relapsing polychondritis }\end{array}$ \\
\hline $\begin{array}{l}\text { Nishino et al. } \\
2006[36]\end{array}$ & $\begin{array}{l}\text { Prospective single-centre } \\
\text { study } \\
\text { To evaluate the frequency } \\
\text { and severity of BM }\end{array}$ & $\begin{array}{l}46 \text { patients (males ( } n=10), \\
\text { females ( } n=36), \text { mean age: } \\
64 \text { years, age range: } 44- \\
84 \text { years) with } \\
\text { bronchiectasis }\end{array}$ & $\begin{array}{l}\text { Volumetric } \\
\text { high-resolution 4- or } \\
\text { 8-detector CT }\end{array}$ & $\begin{array}{l}\mathrm{LAC} \geqslant 50 \% \text { reduction } \\
\text { in the CSA }\end{array}$ & $\begin{array}{l}\text { Prevalence of BM was } \\
\text { found in } 70 \% \text { of } \\
\text { patients at } \\
\text { end-expiration }\end{array}$ & $\begin{array}{l}\text { Air trapping in bronchiectasis } \\
\text { might be greater in } \\
\text { bronchiectasis patients with } \\
\text { BM compared to those } \\
\text { without }\end{array}$ \\
\hline $\begin{array}{l}\text { BARONI et al. } 2005 \\
\text { [38] }\end{array}$ & $\begin{array}{l}\text { Retrospective single-centre } \\
\text { study } \\
\text { To compare the dynamic- } \\
\text { and end-expiratory CT in } \\
\text { assessing LAC }\end{array}$ & $\begin{array}{l}14 \text { patients (males ( } n=11) \text {, } \\
\text { females }(n=3), \text { mean age } \\
53 \text { years old and age range: } \\
19-79 \text { years) with various } \\
\text { conditions }\end{array}$ & $\begin{array}{l}\text { Eight-detector row } \\
\text { helical CT scan }\end{array}$ & $\begin{array}{l}\mathrm{LAC} \geqslant 50 \% \text { reduction } \\
\text { in the CSA }\end{array}$ & $\begin{array}{l}\text { Collapse was greater in } \\
\text { dynamic expiration } \\
\text { than in end-expiration } \\
(p<0.004)\end{array}$ & $\begin{array}{l}\text { The reliance on end-expiratory } \\
\text { imaging alone might result } \\
\text { in a high level of } \\
\text { false-negative results }\end{array}$ \\
\hline $\begin{array}{l}\text { BARONI et al. } 2005 \\
\quad[37]\end{array}$ & $\begin{array}{l}\text { Prospective single-centre } \\
\text { study } \\
\text { To describe the role of pre- } \\
\text { and post-operative } \\
\text { dynamic CT in patients } \\
\text { undergoing tracheoplasty }\end{array}$ & $\begin{array}{l}5 \text { patients (males }(n=4) \text {, } \\
\text { woman }(n=1) ; \text { mean age: } 62 \text {, } \\
\text { age range: } 56-78)\end{array}$ & 8-MDCT helical scan & $\begin{array}{l}\mathrm{TBM} \geqslant 50 \% \text { reduction } \\
\text { in the CSA }\end{array}$ & $\begin{array}{l}\text { Tracheal collapse was } \\
\text { found to be } 58.9 \% \text { pre- } \\
\text { and } 26.9 \% \\
\text { post-operatively during } \\
\text { dynamic expiration }\end{array}$ & $\begin{array}{l}\text { Dynamic expiratory CT is a } \\
\text { potentially valuable tool in } \\
\text { the pre- and post-operative } \\
\text { evaluations of patients } \\
\text { undergoing tracheoplasty }\end{array}$ \\
\hline $\begin{array}{l}\text { NisHiNo et al. } \\
2005 \text { [35] }\end{array}$ & $\begin{array}{l}\text { Prospective single-centre } \\
\text { study } \\
\text { To investigate the } \\
\text { frequency of BM } \\
\text { associated with } \\
\text { sarcoidosis }\end{array}$ & $\begin{array}{l}18 \text { patients (males ( } n=6) \text {, } \\
\text { females ( } n=12 \text { ); mean age: } \\
47 \text { years, age range: } 29- \\
64 \text { years) with pulmonary } \\
\text { sarcoidosis }\end{array}$ & High-Resolution CT & $\begin{array}{l}\mathrm{LAC}>50 \% \text { reduction } \\
\text { in CSA }\end{array}$ & $\begin{array}{l}\text { BM was found in } 61 \% \text { of } \\
\text { patients }\end{array}$ & $\begin{array}{l}\text { BM is frequently associated } \\
\text { with sarcoidosis }\end{array}$ \\
\hline
\end{tabular}


TABLE 2 Continued

\begin{tabular}{|c|c|c|c|c|c|c|}
\hline First author/year & Study purpose and design & Population & Diagnostic modality & Diagnostic criteria & Findings & Discussion \\
\hline $\begin{array}{l}\text { HeUssel et al. } \\
2004 \text { [42] }\end{array}$ & $\begin{array}{l}\text { Prospective single-centre } \\
\text { study } \\
\text { To assess the respiratory } \\
\text { lumen diameter, change } \\
\text { in the tracheal level } \\
\text { during continuous } \\
\text { respiration }\end{array}$ & $\begin{array}{l}38 \text { subjects, } 23 \text { patients with } \\
\text { COPD (age: } 59 \text { years, age } \\
\text { range: } 41-68 \text { years) and } 15 \\
\text { healthy adults (age: } \\
62 \text { years, age range: } 48 \text { to } \\
74 \text { years) }\end{array}$ & Cine-MRI & $\begin{array}{l}\mathrm{LAC}>50 \% \text { reduction } \\
\quad \text { in } \mathrm{CSA}\end{array}$ & $\begin{array}{l}\text { A pathological collapse } \\
\text { occurred in } 33 \% \text { of } \\
\text { volunteers and in } \\
69.6 \% \text { of patients with } \\
\text { COPD }\end{array}$ & $\begin{array}{l}\text { The airway collapse is } \\
\text { significantly larger in } \\
\text { patients with COPD } \\
\text { compared to volunteers }\end{array}$ \\
\hline $\begin{array}{l}\text { HASEGAWA et al. } \\
2003 \text { [21] }\end{array}$ & $\begin{array}{l}\text { Retrospective single-centre } \\
\text { study } \\
\text { To determine the } \\
\text { frequency of TM } \\
\text { incidentally detected on } \\
\text { CT pulmonary } \\
\text { angiography (CTPA) }\end{array}$ & $\begin{array}{l}163 \text { ( } 73 \\
\quad \text { males ( } n=73) \text {, females } \\
\text { ( } n=90) ; \text { mean age: } 60 \text { years) } \\
\text { with suspected pulmonary } \\
\text { embolism }\end{array}$ & $\begin{array}{l}\text { Single detector CT } \\
\text { and MDCT (with } 4 \\
\text { and } 8 \text { detectors) }\end{array}$ & $\begin{array}{r}\mathrm{TM} \geqslant 50 \% \text { decrease } \\
\text { in tracheal lumen }\end{array}$ & $\begin{array}{l}\text { Prevalence of TM was } \\
\text { found in } 10 \% \text { of the } \\
\text { participants with } \\
\text { suspected pulmonary } \\
\text { embolism }\end{array}$ & $\begin{array}{l}\text { TM is a relatively common } \\
\text { finding in CTPA when } \\
\text { assessing patients with } \\
\text { suspected pulmonary } \\
\text { embolism }\end{array}$ \\
\hline $\begin{array}{l}\text { Zhang et al. } 2003 \\
\text { [3] }\end{array}$ & $\begin{array}{l}\text { Prospective single-centre } \\
\text { study } \\
\text { To compare standard- and } \\
\text { low-dose } \mathrm{CT} \text { images } \\
\text { assessing tracheal lumen }\end{array}$ & $\begin{array}{l}10 \text { patients (males ( } n=5) \\
\text { females ( } n=5), \text { mean age: } 56 \\
\pm 11 \text { years) with } \\
\text { bronchoscopically proved } \\
\text { TBM }\end{array}$ & $\begin{array}{l}\text { Multi-section helical } \\
\text { MDCT scan }\end{array}$ & $\begin{array}{l}\mathrm{LAC}>50 \% \text { reduction } \\
\text { in the CSA }\end{array}$ & $\begin{array}{l}\text { TBM was found in all } 10 \\
\text { patients }\end{array}$ & $\begin{array}{l}\text { Paired inspiratory and dynamic } \\
\text { expiratory CT images is a } \\
\text { promising method for } \\
\text { diagnosing TBM }\end{array}$ \\
\hline $\begin{array}{l}\text { AQuino et al. } 2001 \\
\text { [56] }\end{array}$ & $\begin{array}{l}\text { Retrospective and } \\
\text { prospective single-centre } \\
\text { study } \\
\text { To explore the } \\
\text { measurements of the } \\
\text { trachea between } \\
\text { inspiration and } \\
\text { end-expiration on CT }\end{array}$ & $\begin{array}{l}10 \text { TM patients (males ( } n=6 \text { ), } \\
\text { females ( } n=4 \text { ); mean age: } \\
60 \text { years, age range: } 42 \text { to } \\
84 \text { years) and } 23 \text { normal } \\
\text { control patients (males } \\
\text { ( } n=15 \text { ), females ( } n=8) ; \text { mean } \\
\text { age: } 40 \text { years, age range: } 27 \\
\text { to } 57 \text { years) }\end{array}$ & CT scan & $\begin{array}{l}\text { Diagnostic criterion } \\
\text { for TM was not } \\
\text { reported }\end{array}$ & $\begin{array}{l}\text { Collapsibility in tracheal } \\
\text { CSA was significantly } \\
\text { greater in patients with } \\
\text { TM }\left(1.9 \pm 0.9 \mathrm{~cm}^{2}\right) \\
\text { compared to controls } \\
\left(2.4 \pm 0.6 \mathrm{~cm}^{2}\right) \text { during } \\
\text { end-expiration }\end{array}$ & $\begin{array}{l}\text { Patients with TM demonstrate } \\
\text { a higher airway collapse } \\
\text { compared to controls }\end{array}$ \\
\hline $\begin{array}{l}\text { GILKESON et al. } \\
2001 \text { [4] }\end{array}$ & $\begin{array}{l}\text { Prospective single-centre } \\
\text { study } \\
\text { To examine the role of } \\
\text { dynamic } \\
\text { inspiratory-expiratory } \\
\text { imaging with MDCT in } \\
\text { patients with suspected } \\
\text { TBM }\end{array}$ & $\begin{array}{l}13 \text { patients (males ( } n=7 \text { ), } \\
\text { females ( } n=6 \text { ); mean age: } \\
49 \text { years and age range: } 14- \\
88 \text { years) with respiratory } \\
\text { conditions (e.g. asthma, } \\
\text { chronic cough, smoking) }\end{array}$ & $\begin{array}{l}\text { MDCT scan, } \\
\text { bronchoscopy }\end{array}$ & $\begin{array}{l}\mathrm{LAC}>50 \% \text { reduction } \\
\text { in the CSA }\end{array}$ & $\begin{array}{l}\text { All patients showed } \\
\text { evidence of TBM of } \\
\text { different degrees, } 50- \\
75 \%(n=3) 75-100 \% \\
(n=7) \text {, and } 100 \%(n=3)\end{array}$ & $\begin{array}{l}\text { MDCT with } \\
\text { inspiratory-expiratory } \\
\text { imaging is a promising } \\
\text { method in the evaluation of } \\
\text { patients with suspected TBM }\end{array}$ \\
\hline $\begin{array}{l}\text { HeUSSEL et al. } \\
2001[22]\end{array}$ & $\begin{array}{l}\text { Prospective (including } \\
\text { retrospective analysis) } \\
\text { single-centre study } \\
\text { To compare CT, MRI } \\
\text { bronchoscopy, in the } \\
\text { diagnosis of LAC }\end{array}$ & $\begin{array}{l}29 \text { patients (males ( } n=10 \text { ), } \\
\text { females ( } n=19 \text { ); mean age: } \\
61 \text { years, age range: } 27- \\
82 \text { years) with suspicion of } \\
\text { or previously } \\
\text { bronchoscopically verified } \\
\text { tracheal collapse }\end{array}$ & $\begin{array}{l}\text { CT scans (spiral and } \\
\text { cine), cine-MRI, } \\
\text { bronchoscopy }\end{array}$ & $\begin{array}{l}\geqslant 50 \% \text { collapse of the } \\
\text { CSA }\end{array}$ & $\begin{array}{l}\text { Bronchoscopy correlated } \\
\text { with cine CT. MRI } \\
\text { demonstrated similar } \\
\text { time curves of tracheal } \\
\text { CSA to cine CT }\end{array}$ & $\begin{array}{l}\text { Cine CT is able to obtain } \\
\text { significantly improved } \\
\text { evaluation of respiratory } \\
\text { collapse. Cine-MRI promises } \\
\text { functional information due } \\
\text { to free choice of imaging } \\
\text { plane }\end{array}$ \\
\hline
\end{tabular}




\begin{tabular}{|c|c|c|c|c|c|c|}
\hline First author/year & Study purpose and design & Population & Diagnostic modality & Diagnostic criteria & Findings & Discussion \\
\hline $\begin{array}{l}\text { Suto \& TANABE, } \\
1998 \text { [41] }\end{array}$ & $\begin{array}{l}\text { Prospective single-centre } \\
\text { study } \\
\text { To evaluate tracheal } \\
\text { collapsibility during } \\
\text { coughing in patients with } \\
\text { TM who underwent MRI }\end{array}$ & $\begin{array}{l}6 \text { patients (males ( } n=4), \\
\text { females ( } n=2) \text {; mean age: } \\
40 \text { years, age range: } 44 \text { to } \\
68 \text { years) with suspected } \\
\text { TBM and } 13 \text { healthy } \\
\text { volunteers (males }(n=10) \text {, } \\
\text { females ( } n=3) \text {; mean age: } \\
40 \text { years, age range: } 17 \text { to } \\
63 \text { years) }\end{array}$ & $\begin{array}{l}\text { 1.5-T superconducting } \\
\text { MRI system }\end{array}$ & $\begin{array}{l}\text { Diagnostic criterion } \\
\text { for TM was not } \\
\text { reported }\end{array}$ & $\begin{array}{l}\text { Collapse was } 30 \pm 13 \% \text { and } \\
50 \pm 15 \% \text { in forced } \\
\text { expiration, and } 38 \pm 16 \% \\
\text { and } 75 \pm 12 \% \text { during } \\
\text { coughing in healthy } \\
\text { and patients with TM, } \\
\text { respectively }\end{array}$ & $\begin{array}{l}\text { Collapsibility during forced } \\
\text { expiration-inspiration and } \\
\text { collapsibility during } \\
\text { coughing was not significant } \\
\text { in patients with TM during } \\
\text { MRI }\end{array}$ \\
\hline $\begin{array}{l}\text { STERN et al. } 1993 \\
\text { [57] }\end{array}$ & $\begin{array}{l}\text { Prospective single-centre } \\
\text { study } \\
\text { To define the range of } \\
\text { intrathoracic tracheal } \\
\text { diameters and CSA } \\
\text { during forced respiration }\end{array}$ & $\begin{array}{l}10 \text { healthy volunteers (males } \\
(\mathrm{n}=10) \text {, age range: } 24 \\
31 \text { years) }\end{array}$ & $\begin{array}{l}\text { CT using the model } \\
\text { C-100 scanner }\end{array}$ & $\begin{array}{l}\mathrm{TM}>70 \% \text { reduction } \\
\text { in the CSA }\end{array}$ & $\begin{array}{l}\text { Trachea significantly } \\
\text { decreased ( } p<0.001) \\
\text { from end-inspiration } \\
\left(280 \mathrm{~mm}^{2}\right) \text { to } \\
\text { end-expiration } \\
\left(178 \mathrm{~mm}^{2}\right)\end{array}$ & $\begin{array}{l}\text { Intrathoracic tracheal shape, } \\
\text { sagittal and coronal } \\
\text { diameters, and CSA can vary } \\
\text { greatly during a forced } \\
\text { respiration }\end{array}$ \\
\hline
\end{tabular}

\#The studies by Litmanovich et al. 2010 and Boiselle et al. 2009 were not analysed as part of the main results as the participants of both studies were included in O'Donnell et al. 2012. 'The study by Boiselle et al. 2013 was not analysed as part of the main results as the participants were included in O'Donnell et al. 2014. TBM: tracheobronchomalacia; GERD: gastro-oesophageal reflux disease; OSA: obstructive sleep apnoea; MDCT: multi-detector CT; LAC: large airway collapse; CSA: cross-sectional area; EDAC: excessive dynamic airway collapse; CT: computed tomography; TM: tracheomalacia; MRI: magnetic resonance imaging; BM: bronchomalacia; FVC: forced vital capacity; ILD: interstitial lung disease; ECAC: excessive central airway collapse; CF: cystic fibrosis; PE: pulmonary emphysema; CTPA: pulmonary angiography. 
One of the earliest CT studies included in this review performed both spiral and cine CT scans in patients with a suspicion of tracheal stenosis or collapse [22]. Spiral CT was performed during inspiration and during an end-expiratory breath-hold (lasting 20 s) and cine CT was performed during deep and slow breaths. A collapse of $>50 \%$ was found at significantly fewer levels when using paired spiral CT compared to cine CT (13 versus 38\%; $<<0.001)$. For this reason and because the results from cine CT correlated better with bronchoscopic findings (from the same study), the authors concluded that cine CT assesses the magnitude of tracheal collapse more reliably than static inspiratory and expiratory imaging [22].

Other studies describe use of a multi-detector (i.e. two or more detector rows) CT (MDCT) scan [23-26] to assess LAC in patients with respiratory diseases. This approach allows the entire large airway tree to be scanned in $<5 \mathrm{~s}$ offering a high standard of temporal resolution during dynamic expiration which is not possible with a slice by slice or single detector CT [27].

Thirteen studies (37\%) trained the participants regarding breathing technique, prior to CT examination. Sixteen studies (46\%) reported the breathing manoeuvres that were used to assess tendency to airway collapse. Eight studies instructed the participants to breath in, hold (for a count of 2 [28]) and blow out [21, 24, 26, 29-32]. Two studies requested patients to breathe deeply twice, then to exhale as completely as possible before performing a breath-hold, at which point the imaging commenced [33, 34], or to take a deep breath in, blow out all the way and hold breath (four studies; 25\%) [35-38]. McDermott et al. [39] instructed the patients to perform a maximal inspiration and forceful exhalation, whereas Heussel et al. [22] instructed patients to breath slowly and deeply through an open mouth during imaging. Two studies reported that many patients (with suspected pulmonary embolism) were unable to maintain prolonged breath-holds [21], and that inadequate forceful exhalations observed by spirometry trace were repeated [40]. Fourteen studies (out of 35; 40\%) did not report the instructed breathing manoeuvres during the airway collapse assessment.

\section{Magnetic resonance imaging}

Subject characteristics

MRI has been used to assess LAC in four studies (table 2). These studies included a total of 90 participants of which 53 were patients (mean age: 57.9 \pm 6.6 years; 60\% female) with COPD, asthma, relapsing polychondritis and sarcoidosis and 37 were healthy volunteers (mean age: $52.3 \pm 12.3$ years; $23 \%$ female; two studies did not report the age).

\section{Protocols employed}

The first study to use MRI for the evaluation of tracheomalacia [41] used two-dimensional fast sequences. This approach demonstrated that a significant difference in collapsibility occurs during forced expiration and inspiration $(50 \% \pm 15)$, and during coughing $(75 \% \pm 12)$ in patients with tracheomalacia [41]. Moreover, fast acquisition MRI demonstrated excellent temporal resolution, high contrast resolution regardless of imaging plane [41]. A recent study assessed TBM during two 13-s breath-hold end (static)-inspiratory and end-expiratory scans using three-dimensional cine-MRI acquisitions allowing the detection of dynamic TBM in a pseudo real time (i.e. high-speed imaging similar to real time) [31].

All MRI studies included in the review defined LAC as a $>50 \%$ reduction in the CSA (figure 2). One of the studies reported a mean CSA upper tracheal collapse of $42 \%$ (but with a range 20-83\%) in healthy adults and 64\% (range 29-100\%) in COPD patients when evaluating LAC using cine-MRI [42]; however, it did not report the prevalence of LAC, based on a $>50 \%$ reduction in CSA cut-off, in healthy subjects. To elicit expiratory collapse patients were instructed to either breath in, hold and blow out [31] or to breath slowly and deeply through an open mouth during imaging [22, 42]. There were no reports of breathing manoeuvre training prior to the MRI examination or indeed patient cooperation during imaging.

Meta-analyses of LAC prevalence

Healthy controls

The most commonly used criterion to define LAC was a $>50 \%$ reduction in the airway lumen or in the CSA (figure 2). After exclusion of duplicate inclusion of subjects in different studies (see Boiselle et al. [14, 24], Litmanovich et al. [26]), five studies were found to report the prevalence of LAC in healthy volunteers (supplementary e-table 3) [6, 7, 39, 40, 42]. In a random effects meta-analysis of the four studies using the criterion of $>50 \%$ reduction [6, 39, 40, 42], LAC was found in $17 \%$ (95\% CI: $0-61 \%$; $I^{2}=96 \%$ ) (figure 3 ) of healthy subjects. One study using a $>70 \%$ reduction in CSA criterion reported that LAC was present in only $2 \%$ (95\% CI: $0-7 \%)$ [7]. For the studies that were included in the meta-analysis, the mean CSA collapsibility for healthy controls was $39 \pm 17 \%$. There was a considerable heterogeneity among the studies $\left(I^{2}>90 \%\right.$; figure 3$)$, which could be attributed to the different protocols that were 


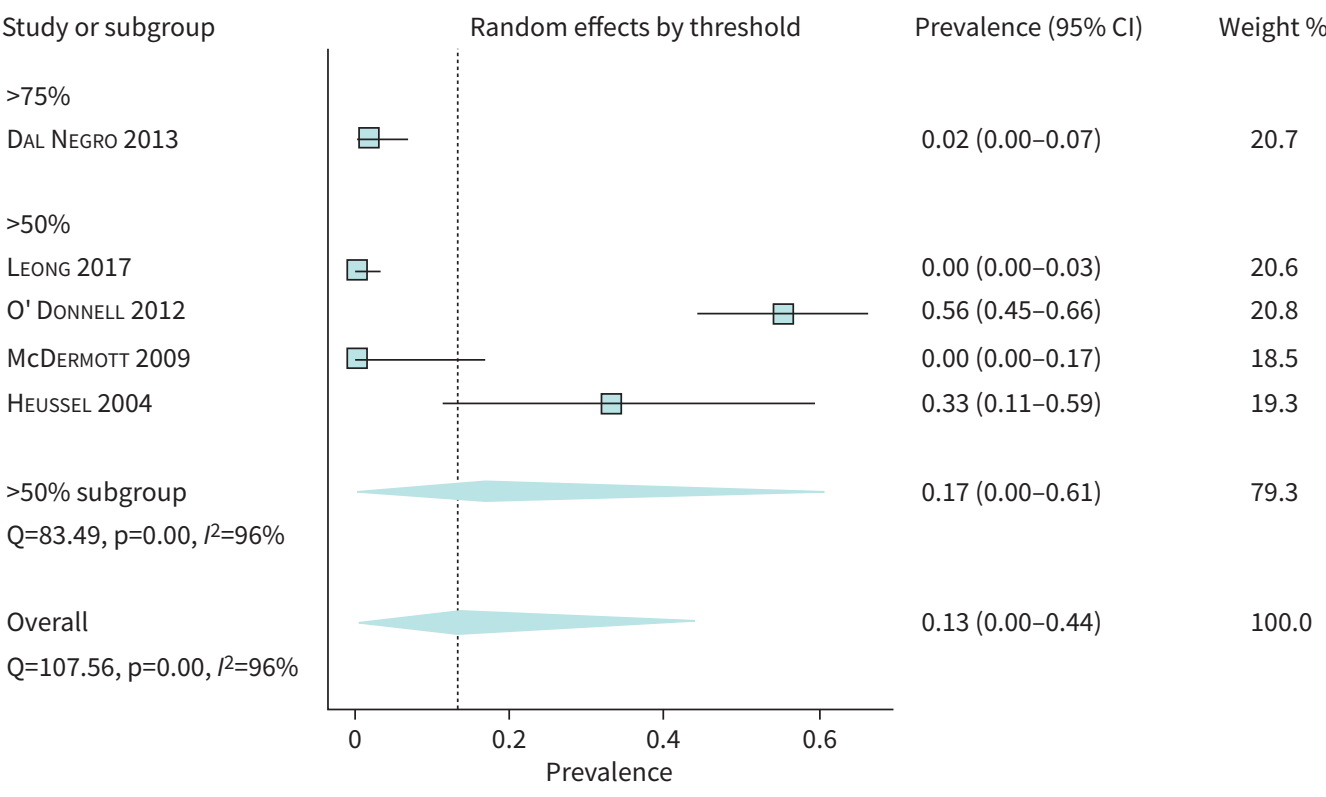

FIGURE 3 Forest plot of the prevalence of large airway collapse in healthy subjects. Random effects meta-analysis was done to estimate the pooled prevalence. Details of included studies, including population, diagnostic modality and threshold, are summarised in table 1.

employed to assess LAC such as the breathing manoeuvres (e.g. forced exhalation, breath-hold, coughing) and technical features (e.g. spiral or cine CT with single or multi-detectors).

\section{Patients with chronic airway diseases}

Thirteen studies reported the prevalence of LAC in patients with chronic airway diseases or smokers, including COPD [6, 7, 24, 33, 34, 42, 43, 44], asthma [7, 34], cystic fibrosis [39], emphysema [45, 46], bronchiectasis [36] or pulmonary sarcoidosis [35]. We performed a meta-analysis for LAC prevalence in eight studies of patients either with COPD or asthma, as the number of studies on other respiratory conditions such as cystic fibrosis, emphysema or bronchiectasis was too small. The studies included in the meta-analysis are summarised in supplementary e-table 4 , and most of them utilised a $>50 \%$ reduction $[6,7$, 33, 34, 42, 43, 44]. LAC was found in 27\% (95\% CI: $11-46 \% ; I^{2}=97 \%$ ) of the included patients (figure 4). One study using the $>80 \%$ criterion found that LAC was present in $20 \%$ (95\% CI: $13-28 \%$ ) in a COPD patient population [24]. For the studies that were included in the meta-analysis, the mean CSA collapsibility for patients with chronic airway diseases was $52 \pm 17 \%$. Heterogeneity among the studies $\left(I^{2}>90 \%\right.$; figure 4$)$ was found to be substantial. This could be explained by the fact that in patients with chronic airway diseases, clinical factors, such as age, disease severity or lung function, are relevant in heterogeneity [7].

\section{Discussion}

It is apparent from this systematic review that over the past 30 years, a wide variety of approaches have been evaluated in the diagnostic evaluation of LAC. Bronchoscopy has long been considered the "gold standard" diagnostic test by clinicians; however, our review process reveals that CT has actually been the most commonly reported modality in the published literature over this time period. Indeed, CT has been utilised in $80 \%$ of all published LAC studies and there are only three papers detailing bronchoscopic evaluation of LAC, within the contemporary literature. The review process also reveals that, to the best of our knowledge, there are no published data describing the "normal" or healthy large airway response to expiratory manoeuvres, using bronchoscopic techniques. In addition, although a $>50 \%$ reduction in large airway calibre appears to be, at least anecdotally, the most widely used diagnostic criterion in clinical practice, and indeed is reported in half of the papers included in this review, this degree of LAC was encountered in one in five asymptomatic and entirely healthy subjects undergoing dynamic expiratory CT imaging. Overall, the findings thus might challenge several assumptions widely held, with respect to the most widely researched diagnostic technique and cut-off values used for the diagnosis of LAC.

Accurate detection and diagnosis of LAC is important to facilitate selection and delivery of treatments that may improve patient QoL and reduce healthcare utilisation [47, 48]. Recent work has highlighted 


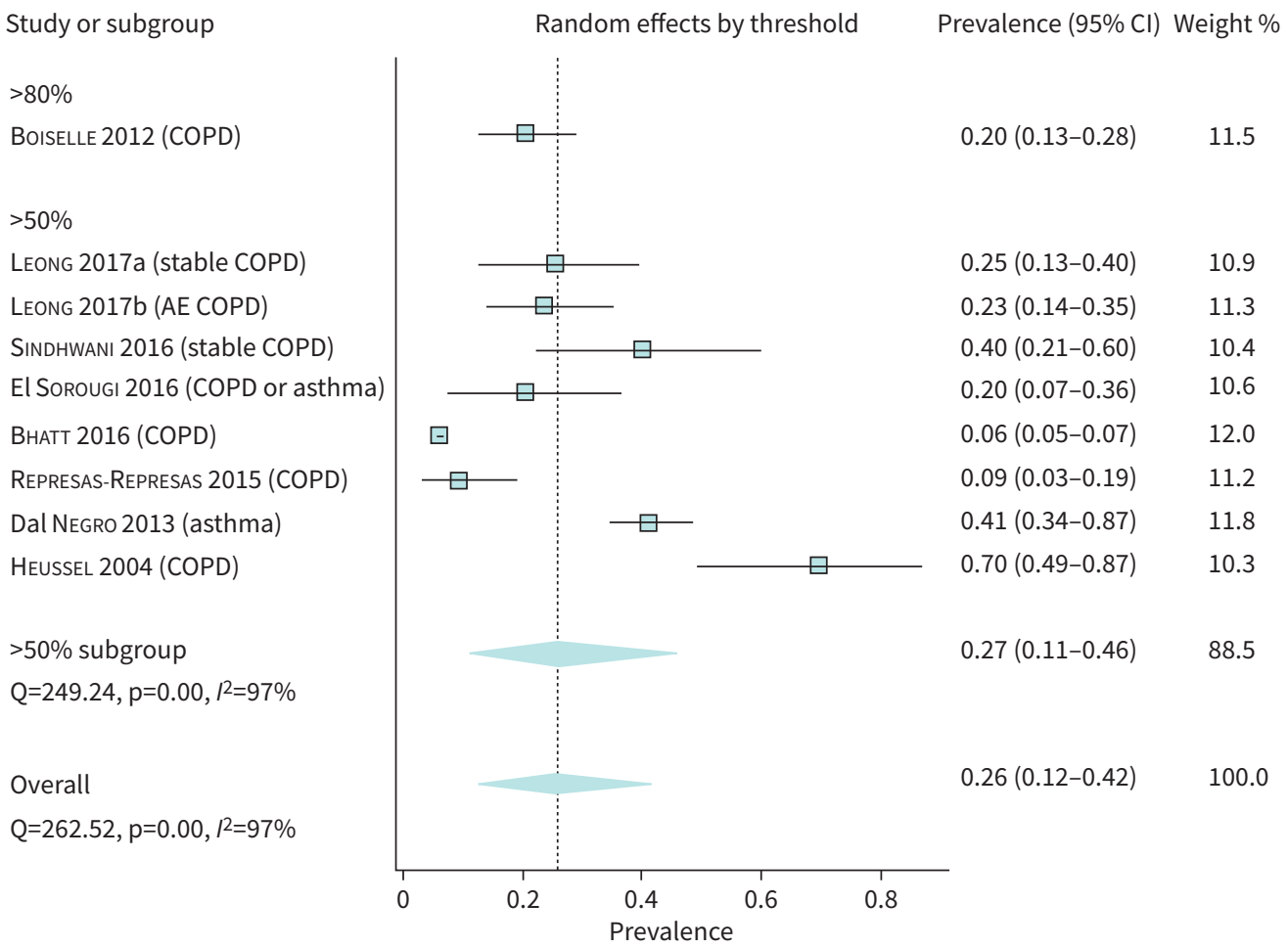

FIGURE 4 Forest plot of the prevalence of large airway collapse in patients with chronic obstructive airway diseases (either COPD or asthma). Random effects meta-analysis was done to estimate the pooled prevalence. Details of included studies, including population, diagnostic modality, and threshold, are summarised in table 2 . AE: acute exacerbation.

favourable outcomes with tracheobronchoplasty, and thus it is important that clinicians are able to apply robust and reproducible diagnostic parameters, to reliably detect LAC and consider referral for intervention. A key clinical challenge in this area is the ability to differentiate between physiological and pathological (i.e. clinically relevant) collapse. In this respect, the finding that almost one in five healthy individuals appear to have LAC of $>50 \%$ on CT (figure 3), challenges the notion that collapse of this severity immediately implicates a disease state. The degree of airway collapse does, however, appear to relate to age, certainly in healthy male volunteers, such that the mean collapse in males aged 24-31 years old was $36 \%$ [40]. In contrast, very few healthy (2\%) individuals demonstrated LAC $>70 \%$ in the studies reviewed, suggesting a more conservative diagnostic cut-off may be more appropriate. However, even in the context of more marked airway collapse (e.g. $>70 \%$ ), it can remain challenging to decipher the relationship between degree of collapse and collapse that induces "clinically relevant" flow limitation and/or symptoms. For example, the degree of LAC observed in patients with COPD appears to relate poorly to pulmonary function and functional capacity (e.g. exercise walking test) [24]. These findings should be interpreted with caution due to the considerable heterogeneity that was observed among studies in healthy subjects which could be explained by the variety of methodologies that were employed to assess LAC, such as a broad range of breathing manoeuvres (e.g. forced exhalation, breath-hold, coughing) and technical features (e.g. spiral or cine CT with single or multi-detectors). Some researchers in this field have sought to extend the diagnostic assessment criteria, proposing a more detailed assessment that incorporates an admixture of clinical and imaging/bronchoscopic findings, to help characterise the relevance and functional implications of LAC. Others have highlighted the importance of determining the location of any flow-limiting segment or choke point (i.e. stent insertion at flow-limiting segments has been shown to restore the rigidity of the involved airway segment [49]). Certainly, the relevance of findings arising from a forced dynamic expiratory manoeuvre phase is uncertain from a physiological standpoint [24, 26, 40], especially when compared with more applicable physiological challenges such as exercise or assessment of other symptoms such as cough or recurrent infections.

The interplay and differentiation between pathology and physiology becomes increasingly complex, but clinically relevant, in scenarios whereby the interplay between pleural and intraluminal forces increasingly favours airway closure (e.g. in obesity or emphysema). The current review revealed that LAC was present 
in approximately a third of patients with obstructive airways disease. This was a heterogeneous group but mostly defined by the study authors as patients with COPD. Whilst intervention for LAC in this context may improve QoL, it is not always associated with direct and measurable changes in allied physiological measures. In addition, differentiating obstructive pulmonary function findings from those arising from LAC is not straightforward.

Flexible bronchoscopy is considered the "gold standard" approach to LAC diagnosis by many clinicians since it permits real-time evaluation of the dynamic airway properties, at several sites and with the ability to provide direct instruction. It also permits repeated and sequential assessments during different manoeuvres (e.g. tidal breathing, forced dynamic manoeuvres and coughing) and allows airway sampling to be undertaken. This has to be countered by the fact that bronchoscopy is an invasive assessment and in contrast, the latest advances in CT technology have resulted in faster speed, greater breadth and enhanced spatial resolution, facilitating more precise airway luminal measurement [6, 29]. MDCT has the ability to obtain a large amount of data of the entire central airways in only a few seconds compared to bronchoscopy. A few studies have compared dynamic expiratory CT with bronchoscopy (as the diagnostic "gold standard") for the diagnosis of LAC. In the study by LeE et al. [50] dynamic expiratory CT (e.g. end-inspiratory, and dynamic expiratory imaging) compared well with bronchoscopy in patients with TBM. Namely, CT and bronchoscopic findings showed a good level of agreement with respect to the presence, severity and distribution of TBM in 97\% (diffuse TBM in 82\%; bronchomalacia in 11\%; tracheomalacia in $7 \%$ ) of patients. Cine-MRI is advantageous in reducing radiation exposure and can improve temporal resolution [31], and it may be useful for therapeutic monitoring (e.g. measurement of dynamic luminal diameter change)/evaluating response to treatment.

The reproducibility of any diagnostic technique is important to consider if it has implications for subsequent clinical intervention. In our review, we found that bronchoscopy was associated with a good degree of interand intra-observer levels of agreement, irrespective of level of training and experience [19].

\section{Methodological considerations}

There are several limitations to consider in the interpretation of our meta-analysis. First, the numbers of included studies in quantitative analyses were small, and they were all conducted at single centres. Thus, our meta-analyses are explorative and may not be an entirely inclusive representation of the findings of the prevalence of LAC in healthy subjects. However, two studies [14, 26] clearly pointed out that the diagnostic criterion of $>50 \%$ may classify $55-78 \%$ of healthy subjects as abnormal. Second, there was a considerable heterogeneity among the studies $\left(I^{2}>90 \%\right.$; figures 3 and 4$)$, which could not be fully investigated because of the limited number of relevant studies, and thus, our results should be interpreted with caution. In patients with chronic airway diseases, certain clinical factors such as age, disease severity or lung function are likely to underpin heterogeneity[7]. In healthy controls, however, the reason for a difference between the studies could be associated to the variety of investigation protocols and diagnostic criteria that were utilised. However, two studies [40, 42] clearly showed that the diagnostic criterion of $>50 \%$ may result in false positives in nonsmokers without respiratory symptoms or history. Third, publication bias could not be assessed because of a small number of included studies. Fourth, it should be acknowledged that the results need to be cautiously interpreted; considering the heterogeneity in respiratory pathologies included in this review (e.g. COPD, asthma, cystic fibrosis or emphysema), as well as the variety of diagnostic modalities to assess LAC (e.g. bronchoscopy, CT, MRI). For example, owing to the heterogeneity in the airway diseases and diagnostic modalities we were only able to estimate the prevalence of LAC in COPD or asthma patients (figure 4).

\section{Conclusion}

Our systematic review reveals that, over the past 30 years, a large number of studies (including over 10500 subjects) have been published evaluating LAC, using a broad variety of investigation protocols and diagnostic criteria. It is likely, however, that the broad range of approaches to assessment and diagnosis has led to the high level of heterogeneity that was observed in our systematic review and, as such, limits robust conclusions being drawn regarding precise cut-off values. Moreover, the varying study methodologies and outcome measures are confusing to interpret for both the clinician and researcher, and whilst $\mathrm{a} \geqslant 50 \%$ reduction in calibre of the central airway lumen on inspiratory to expiratory CT is the most commonly described diagnostic criterion, this is likely to be confounded by poor diagnostic specificity. Regardless, at this diagnostic threshold, LAC appears to be a frequent comorbidity in patients with COPD or asthma. Overall, these findings highlight the need for improved international consensus regarding the best approach to this condition, agreement regarding diagnostic criteria and further scientific work to establish the physiological and disease implications of LAC. 
Author contributions: A. Mitropoulos, F. Almaghlouth and W-J. Song performed the systematic review and meta-analysis. A. Mitropoulos, W-J. Song and J.H. Hull contributed substantially to the study design, data analysis and the writing of the manuscript. M.I. Polkey and S. Kemp contributed to the interpretation of the results. A. Mitropoulos takes full responsibility for the integrity of the systematic review as a whole.

Conflict of interest: All authors declare that they have no affiliations with or involvement in any organisation or entity with any financial interest or nonfinancial interest in the subject matter or materials discussed in this manuscript.

Support statement: We would like to thank the RELACS charity and the Royal Brompton Hospital Charity that funded A. Mitropoulos' salary.

References

1 Murgu S, Colt H. Tracheobronchomalacia and excessive dynamic airway collapse. Clin Chest Med 2013; 34: 527-555.

2 Nuutinen J. Acquired tracheobronchomalacia. A bronchological follow-up study. Ann Clin Res 1977; 9: 359-364

3 Zhang J, Hasegawa I, Feller-Kopman D, et al. 2003 AUR memorial award. dynamic expiratory volumetric CT imaging of the central airways: comparison of standard-dose and low-dose techniques. Acad Radiol 2003; 10: 719-724.

4 Gilkeson RC, Ciancibello LM, Hejal RB, et al. Tracheobronchomalacia: dynamic airway evaluation with multidetector CT. AJR Am J Roentgenol 2001; 176: 205-210.

5 Ikeda S, Hanawa T, Konishi T, et al. Diagnosis, incidence, clinicopathology and surgical treatment of acquired tracheobronchomalacia. Nihon Kyobu Shikkan Gakkai Zasshi 1992; 30: 1028-1035.

6 Leong P, Tran A, Rangaswamy J, et al. Expiratory central airway collapse in stable COPD and during exacerbations. Respir Res 2017; 18: 163.

7 Dal Negro R, Tognella S, Guerriero M, et al. Prevalence of tracheobronchomalacia and excessive dynamic airway collapse in bronchial asthma of different severity. Multidiscip Respir Med 2013; 8: 32.

8 Hopkinson NS, Dayer MJ, Moxham J, et al. Abdominal muscle fatigue following exercise in chronic obstructive pulmonary disease. Respir Res 2010; 11: 15.

9 Murphy P, Arbane G, Jayaram D, et al. The effect of volume targeted pressure support (PS) ventilation with autotitrating expiratory positive airways pressure (EPAP) and back up rate (BUR) on sleep quality in COPD-obstructive sleep apnoea (OSA) overlap syndrome. Eur Respir J 2013; 42: Suppl. 57, P2583. http://erj. ersjournals.com/content/42/Suppl_57/P2583.abstract.

10 Majid A, Guerrero J, Gangadharan S, et al. Tracheobronchoplasty for severe tracheobronchomalacia: a prospective outcome analysis. Chest 2008; 134: 801-807.

11 Rayl JE. Tracheobronchial collapse during cough. Radiology 1965; 85: 87-92.

12 Feist JH, Johnson TH, Wilson RJ. Acquired tracheomalacia: etiology and differential diagnosis. Chest 1975; 68: 340-345.

13 Jokinen K, Palva T, Sutinen S, et al. Acquired tracheobronchomalacia. Ann Clin Res 1977; 9: 52-57.

14 Boiselle PM, O'Donnell CR, Bankier AA, et al. Tracheal collapsibility in healthy volunteers during forced expiration: assessment with multidetector CT. Radiology 2009; 252: 255-262.

15 Hoy D, Brooks $\mathrm{P}$, Woolf $\mathrm{A}$, et al. Assessing risk of bias in prevalence studies: modification of an existing tool and evidence of interrater agreement. J Clin Epidemiol 2012; 65: 934-939.

16 Whiting PF, Rutjes AW, Westwood ME, et al. QUADAS-2: a revised tool for the quality assessment of diagnostic accuracy studies. Ann Intern Med 2011; 155: 529-536.

17 Egger M, Davey Smith G, Schneider M, et al. Bias in meta-analysis detected by a simple, graphical test. BMJ 1997; 315: 629-634.

18 Murgu SD, Colt HG. Description of a multidimensional classification system for patients with expiratory central airway collapse. Respirology 2007; 12: 543-550.

19 Majid A, Gaurav K, Sanchez JM, et al. Evaluation of tracheobronchomalacia by dynamic flexible bronchoscopy. A pilot study. Ann Am Thorac Soc 2014; 11: 951-955.

20 Boiselle PM, Lee KS, Lin S, et al. Cine CT during coughing for assessment of tracheomalacia: preliminary experience with 64-MDCT. AJR Am J Roentgenol 2006; 187: W175-W177.

21 Hasegawa I, Boiselle PM, Raptopoulos V, et al. Tracheomalacia incidentally detected on CT pulmonary angiography of patients with suspected pulmonary embolism. AJR Am J Roentgenol 2003; 181: 1505-1509.

22 Heussel CP, Hafner B, Lill J, et al. Paired inspiratory/expiratory spiral CT and continuous respiration cine CT in the diagnosis of tracheal instability. Eur Radiol 2001; 11: 982-989.

23 Ciet P, Boiselle PM, Michaud G, et al. Optimal imaging protocol for measuring dynamic expiratory collapse of the central airways. Clin Radiol 2016; 71: e49-e55. 
Assoc Radiol $\mathrm{J}$ 2010, 61: 90-97. 2019; 146: 124-128.

30 Nygaard M, Bendstrup E, Dahl R, et al. Tracheal collapse diagnosed by multidetector computed tomography: evaluation of different image analysis methods. Eur Clin Respir J 2017; 4: 1407624.

31 Ciet P, Boiselle PM, Heidinger B, et al. Cine MRI of tracheal dynamics in healthy volunteers and patients with tracheobronchomalacia. AJR Am J Roentgenol 2017; 209: 757-761.

32 Boiselle PM, O'Donnell CR, Loring SH, et al. Reproducibility of forced expiratory tracheal collapse: assessment with MDCT in healthy volunteers. Acad Radiol 2010; 17: 1186-1189.

33 El Sorougi W, Abdel-Hafiz H, Fathy S. Diagnostic utility of dynamic CT in tracheomalacia in COPD patients. Egypt J Chest Dis Tuberc 2016; 65: 563-566.

34 Sindhwani G, Sodhi R, Saini M, et al. Tracheobronchomalacia/excessive dynamic airway collapse in patients with chronic obstructive pulmonary disease with persistent expiratory wheeze: a pilot study. Lung India 2016; 33: 381-384.

35 Nishino $\mathrm{M}$, Kuroki $\mathrm{M}$, Roberts $\mathrm{DH}$, et al. Bronchomalacia in sarcoidosis: evaluation on volumetric expiratory high-resolution CT of the lung. Acad Radiol 2005; 12: 596-601.

36 Nishino M, Siewert B, Roberts $\mathrm{DH}$, et al. Excessive collapsibility of bronchi in bronchiectasis: evaluation on volumetric expiratory high-resolution CT. J Comput Assist Tomogr 2006; 30: 474-478.

37 Baroni RH, Ashiku S, Boiselle PM. Dynamic CT evaluation of the central airways in patients undergoing tracheoplasty for tracheobronchomalacia. AJR Am J Roentgenol 2005; 184: 1444-1449.

38 Baroni RH, Feller-Kopman D, Nishino M, et al. Tracheobronchomalacia: comparison between end-expiratory and dynamic expiratory CT for evaluation of central airway collapse. Radiology 2005; 235: 635-641.

39 McDermott S, Barry SC, Judge EP, et al. Tracheomalacia in adults with cystic fibrosis: determination of prevalence and severity with dynamic cine CT. Radiology 2009; 252: 577-586.

40 O'Donnell CR, Litmanovich D, Loring SH, et al. Age and sex dependence of forced expiratory central airway collapse in healthy volunteers. Chest 2012; 142: 168-174.

41 Suto Y, Tanabe Y. Evaluation of tracheal collapsibility in patients with tracheomalacia using dynamic MR imaging during coughing. AJR Am J Roentgenol 1998; 171: 393-394.

42 Heussel CP, Ley S, Biedermann A, et al. Respiratory lumenal change of the pharynx and trachea in normal subjects and COPD patients: assessment by cine-MRI. Eur Radiol 2004; 14: 2188-2197.

43 Represas-Represas C, Leiro-Fernández V, Mallo-Alonso R, et al. Excessive dynamic airway collapse in a small cohort of chronic obstructive pulmonary disease patients. Ann Thorac Med 2015; 10: 118-122.

44 Bhatt SP, Terry NL, Nath $\mathrm{H}$, et al. Association between expiratory central airway collapse and respiratory outcomes among smokers. JAMA 2016; 315: 498-505.

45 Inoue M, Hasegawa I, Nakano K, et al. Incidence of tracheobronchomalacia associated with pulmonary emphysema: detection with paired inspiratory-expiratory multidetector computed tomography using a low-dose technique. Jpn J Radiol 2009; 27: 303-308.

46 Ochs RA, Petkovska I, Kim HJ, et al. Prevalence of tracheal collapse in an emphysema cohort as measured with end-expiration CT. Acad Radiol 2009; 16: 46-53.

47 Murgu SD, Colt HG. Treatment of adult tracheobronchomalacia and excessive dynamic airway collapse: an update. Treat Respir Med 2006; 5: 103-115.

48 Kheir F, Majid A. Tracheobronchomalacia and excessive dynamic airway collapse: medical and surgical treatment. Semin Respir Crit Care Med 2018; 39: 667-673.

49 Miyazawa T, Miyazu Y, Iwamoto Y, et al. Stenting at the flow-limiting segment in tracheobronchial stenosis due to lung cancer. Am J Respir Crit Care Med 2004; 169: 1096-1102.

50 Lee KS, Sun MRM, Ernst A, et al. Comparison of dynamic expiratory CT with bronchoscopy for diagnosing airway malacia: a pilot evaluation. Chest 2007; 131: 758-764.

51 Bezuidenhout AF, Boiselle PM, Heidinger $\mathrm{BH}$, et al. Longitudinal follow-up of patients with tracheobronchomalacia after undergoing tracheobronchoplasty: computed tomography findings and clinical correlation. J Thorac Imaging 2019; 34: 278-283. 
52 Weinstein DJ, Hull JE, Ritchie BL, et al. Exercise-associated excessive dynamic airway collapse in military personnel. Ann Am Thorac Soc 2016; 13: 1476-1482.

53 Wielpütz MO, Eberhardt R, Puderbach M, et al. Simultaneous assessment of airway instability and respiratory dynamics with low-dose 4D-CT in chronic obstructive pulmonary disease: a technical note. Respiration 2014; 87: 294-300.

54 Boiselle PM, Litmanovich DE, Michaud G, et al. Dynamic expiratory tracheal collapse in morbidly obese COPD patients. COPD 2013; 10: 604-610.

55 Lee KS, Ernst A, Trentham DE, et al. Relapsing polychondritis: prevalence of expiratory CT airway abnormalities. Radiology 2006; 240: 565-573.

56 Aquino SL, Shepard JA, Ginns LC, et al. Acquired tracheomalacia: detection by expiratory CT scan. J Comput Assist Tomogr 2001; 25: 394-399.

57 Stern EJ, Graham CM, Webb WR, et al. Normal trachea during forced expiration: dynamic CT measurements. Radiology 1993; 187: 27-31. 